\title{
Amber, beads and social interaction in the Late Prehistory of the Iberian Peninsula: an update
}

\author{
Carlos P. Odriozola $^{1} \cdot$ Ana C. Sousa $^{2} \cdot$ Rui Mataloto $^{3} \cdot$ Rui Boaventura $^{2}$. \\ Marco Andrade ${ }^{2}$ - Rodrigo Villalobos García ${ }^{4}$. José Ángel Garrido-Cordero ${ }^{1}$. \\ Eugenio Rodríguez ${ }^{1}$ • José María Martínez-Blanes ${ }^{5}$ - Miguel Ángel Avilés ${ }^{5}$. \\ Joan Daura ${ }^{2} \cdot$ Montserrat Sanz $^{6}$ • José Antonio Riquelme ${ }^{7}$
}

Received: 24 March 2017 / Accepted: 4 October 2017

(C) Springer-Verlag GmbH Germany 2017

\begin{abstract}
The identification of archaeological amber has been used in Iberian prehistory to evidence long-distance exchanges and engage Iberia in networks that connect western Europe with central and northern Europe, the emergence of social complexity, and the consolidation of trade networks. However, until now, no comprehensive analytical study of the Iberian amber has been produced to support any of the interpretive models currently in use. This paper approaches the analysis of Iberian Peninsula amber artefacts by considering their provenance (based on FTIR characterization), chronology, and spatial relationship with other exotica. Our work increases the number of analyzed artefacts to 156 (24\%), out of the c. 647 currently known for the Iberian Peninsula. Based on these new data and a review
\end{abstract}

Carlos P. Odriozola

codriozola@us.es

1 Dpto. de Prehistoria y Arqueología, Universidad de Sevilla, C. María Padilla S/N, 41004 Sevilla, Spain

2 UNIARQ, Centro de Arqueologia da Universidade de Lisboa, Lisbon, Portugal

3 Cámara Municipal de Redondo, UNIARQ, Centro de Arqueologia da Universidade de Lisboa, Lisbon, Portugal

4 Dpto. de Prehistoria, Arqueología, Antropología Social y Ciencias y Técnicas Historiográficas, Universidad de Valladolid, Lisbon, Portugal

5 Consejo Superior de Investigaciones Científicas, Instituto de Ciencia de Materiales de Sevilla, Seville, Spain

6 Departamento de Paleontología, Facultad de Ciencias Geológicas, Centro UCM-ISCIII de Investigación sobre la Evolución y Comportamiento Humanos, Universidad Complutense de Madrid, Madrid, Spain

7 Departamento de Geografía y Ciencias Del Territorio, Universidad de Córdoba, Córdoba, Spain of Murillo-Barroso and Martinón-Torres (2012), this overview outlines amber consumption patterns from the 6th to 2nd millennia BCE and demonstrates long-distance amber exchange connecting Iberia with the Mediterranean region from the Neolithic period onwards.

Keywords Amber $\cdot$ FTIR $\cdot$ Iberia $\cdot$ Provenance $\cdot$ Prehistory

\section{Introduction}

The identification of archaeological amber has been used in Iberian prehistory to evidence long-distance exchanges and engage Iberia in networks that connect western Europe with central and northern Europe. However, assuming a Baltic origin for these ambers is not usually supported by analytical data and numerous deposits are found in Spain, Italy, France, Germany, Austria, Switzerland, Hungary and Romania (Poinar 1992; Kosmowska-Ceranowicz 1999; Rice 2006; Angelini and Bellintani 2016).

With the exception of Siret's pioneering attempt in 1913 (Siret 1913), it was not until the start of the twenty-first century, paralleling scientific developments in instrumentation and methods, that systematic provenance analyses of Iberian amber were performed. Beginning in the 1960s, pioneering analytical studies by Beck (Beck et al. 1964, 1965; Beck 1965) paralleled the first inventories of amber artefacts in Portugal (Ferreira 1966) and the increasing attention paid to amber finds in archaeological reports. Since then, analytical studies have relied strongly on infrared spectroscopy (FTIR), nuclear magnetic resonance and gas chromatography as ways to determine the botanical and geographical origin of amber (Stout et al. 2000). FTIR became the standard technique in archaeology and was the first technique capable of 
determining the Baltic origin of amber through the presence of a distinct feature in its infrared spectrum: the 'Baltic shoulder' (Beck et al. 1964, 1965, Beck 1965, 1982). However, the limits of this method appeared to be reached when it proved less successful in distinguishing between non-Baltic ambers due to a misclassification of copal as simetite. Once that had been solved, the characteristic FTIR simetite spectrum was clearly determined (Beck and Hartnett 1993). In addition, the discovery of geological sources of amber within the Iberian Peninsula in the 1990s (Rovira i Port 1994; Domínguez-Bella et al. 2001; Álvarez Fernández et al. 2005; Delclòs et al. 2007; Peñalver et al. 2007; Cerdeño et al. 2012) has challenged the capabilities of this technique, broadened the range of possibilities and reinforced the dangers of assuming amber provenance without supporting analytical evidence. A further limitation stems from the relative scarcity of analytical studies and absolute dating (see Tables 1 and 3).

Between the 6th and 2nd millennia BCE, the Iberian Peninsula underwent a process of increasing social complexity (Chapman 2008) evidenced by the appearance of protourban settlements - enclosures, agricultural and livestock intensification - consolidation of the secondary products revolution, the development of certain crafts - in copper metallurgy, ivory..., and the appearance of profound social inequalities. In this context, personal adornments, understood as sociotechnical artefacts (sensu Binford 1962), are a perfect archaeological indicator of social complexity as they are assumed to mark personal/individual status. Even though the amount of labour involved in the manufacture of these items was not necessarily very great (Villalobos García and Odriozola 2016), the use of exotic or rare materials (Alday Ruiz 1987; Pascual Benito 1999; Bueno Ramírez et al. 2005; Costa et al. 2011; Marqués Merelo and Aguado Mancha 2012 in the manufacture of personal adornments suggests a clear interest in gathering restricted and/or exclusive items to be used as status markers during social action. In addition to amber, some materials, such as alpine jade in the 6th to 4th millennia BCE (Pétrequin et al. 2012), variscite in the 4th to 2nd millennia BCE (Odriozola et al. 2016b; Villalobos García and Odriozola 2016) and ivory during the 3rd and 2nd millennia BCE (Schuhmacher 2012), were exchanged, traded or trafficked across Europe within interwoven networked social relationships.

This paper approaches the analysis of Iberian Peninsula amber artefacts by considering their provenance, chronology, and, most importantly, their spatial relationship with other exotica. It signifies a great advance in this field, as it increases the number of analyzed artefacts to $\mathbf{1 5 6}$. This occasion has been used to furnish additional and revised information to the inventory of Murillo-Barroso and Martinón-Torres (2012).

\section{Case studies}

\section{Anta da Capela}

The first amber artefacts studied and reported here were recovered during archaeological excavation in Anta da Capela, Avis (CNS 3201), by Silva and Vasconcellos in 1893. There is no agreement between the excavators when referring to the finds inside this megalith, as each one published a different inventory (see de Silva 1895; Vasconcellos 1910).

Anta da Capela is a medium size megalithic passage grave, poorly preserved. Most of the orthostats from the chamber were broken or displaced (some of them even before the excavation in the nineteenth century), and currently only two of them remain in their original position. The monument itself still preserves the passage and the mound, a feature which is still visible in the landscape.

The finds deposited in the National Archaeological Museum (Lisbon) are apparently incomplete, as not all the published artefacts were finally deposited in the museum. However, the finds are represented by a typical Late Neolithic/Early Copper Age assemblage, consisting of small hemispherical bowls, amphibolite axes and adzes, prismatic bladelet cores and bladelets of hyaline quartz, retouched flint blades, two flint microliths (trapezoids), 38 flint and hyaline quartz arrowheads of different typologies (with triangular, concave or convex base), an engraved schist plaque, and three sandstone plaques, one of which preserves red pigmentation on its surfaces. The amber nodule (MNA 2006.74.68) studied here (Fig. 1) appeared together with an assemblage of $c .500$ beads worked in slate, talc, muscovite, variscite (MNA 2003.74.67), ceramic and ivory (Schuhmacher et al. 2009: 990-991); and a set of bone "hair-pins" with detachable head (plain and grooved) and perforated canines of Canis.

Human remains recorded in the publications are represented by numerous elements, accounting for c. 1000 teeth and a bone "disc" from a trepanned cranium. However, only a few teeth and a small assemblage of fragmented long bones and maxillae are preserved in the museum, from which a sample of human humerus (MNA 2003.74.96) was submitted for C14-AMS dating (CNA3543.1.1: $4532 \pm 30$ BP). The homogeneity of the votive assemblage, and its features, situates the use episodes of this monument between 3200 and $2800 \mathrm{BCE}$; the absence of elements no more recent than the second quarter of the 3rd millennium BCE indicate that the "exotic" materials at this monument (such as amber, ivory and even the variscite) are attributable to an occupation centred in the transition from the 4th to the 3rd millennium BCE (and the first centuries of the latter). 
Table 1 A summary of Iberian archaeological sites from the 6th to the 2nd millennia BCE with published provenance analyses, a re-evaluation of provenance made by the authors, and reassessed chronological adscription of the finds. If absolute dates are not available, the chronological adscription has been based on associated archaeological materials and stratigraphy

\begin{tabular}{|c|c|c|c|c|c|c|c|}
\hline No. & Site & \# & \# & Context & FTIR & This paper & Reference \\
\hline \multicolumn{8}{|c|}{ Neolithic (5th to 4th millennia BCE) } \\
\hline 1 & $\begin{array}{l}\text { Sepulcro tumular } \\
\text { de Cal Rajolí }\end{array}$ & 1 & & Barrow & & & (Rovira i Port 1994: 71-73) \\
\hline 2 & $\begin{array}{l}\text { Domen } \\
\text { de Alberite }\end{array}$ & 3 & 1 & Megalith & Simetite/doubtful ${ }^{\mathrm{a}}$ & & (Domínguez-Bella et al. 2001: 627) \\
\hline 3 & $\begin{array}{l}\text { Dolmen de } \\
\text { Mamoa V de } \\
\text { Chã de Arcas }\end{array}$ & 1 & 1 & Megalith & Simetite & & (Vilaça et al. 2002: 62) \\
\hline 4 & Chousa Nova & 15 & 2 & Barrow & Simetite/doubtful ${ }^{1}$ & & (Dominguez Bella and Bóveda 2011) \\
\hline 5 & El Juncal & 1 & & Megalith & & & (Gutiérrez López 2007: 298) \\
\hline 6 & Orca de Seixas & 1 (lost) & & Megalith & & & (Vilaça et al. 2002: 72) \\
\hline 7 & $\begin{array}{l}\text { Anta dos } \\
\text { Pombais }\end{array}$ & 4 & & Megalith & & & (Oliveira 1992: 58; Vilaça et al. 2002: 74) \\
\hline 9 & $\begin{array}{l}\text { Necrópolis } \\
\text { de Campo } \\
\text { de Hockey }\end{array}$ & 3 & & Cist & Non-Baltic & $\begin{array}{l}\text { Spectrum } \\
\text { not } \\
\text { available }\end{array}$ & (Vijande Vila et al. 2015: 156-158) \\
\hline 10 & $\begin{array}{l}\text { Cueva de los } \\
\text { Cuarenta }\end{array}$ & 1 & & Cave & & & (Vera Rodríguez 2014: 107, 118) \\
\hline 11 & $\begin{array}{l}\text { Dolmen } \\
\text { de la Rosa }\end{array}$ & $\begin{array}{l}\text { Fragments } \\
\text { (lost) }\end{array}$ & & Megalith & & & Pers. Com. (J.M. Gutiérrez) \\
\hline 12 & Anta da Capela & 1 & 1 & Megalith & & Simetite & \\
\hline \multirow[t]{2}{*}{13} & La Velilla & 1 & & Megalith & & & (Álvarez Fernández et al. 2005: 167) \\
\hline & $\Sigma$ & $>33$ & 5 & & & & \\
\hline \multicolumn{8}{|c|}{ Copper Age (3rd millennium BCE) } \\
\hline 14 & La Encantada ${ }^{\mathrm{b}}$ & 0 & & Tholos & & & $\begin{array}{l}\text { (Molina Fajardo and Cámara Serrano 2009: 312; } \\
\text { Costa et al. 2011: } 261 \text { Table 4) }\end{array}$ \\
\hline 15 & $\begin{array}{l}\text { Errekatxuetako } \\
\quad \text { Atxa }\end{array}$ & 1 & & Megalith & & & (López Quintana 2015) \\
\hline 16 & $\begin{array}{l}\text { Anta Grande } \\
\text { do Zambujeiro }\end{array}$ & 168 & 5 & Megalith & & Simetite & (Vilaça et al. 2002: 75-76) this paper \\
\hline 17 & Las Arnillas ${ }^{\mathrm{c}}$ & fragments & & Megalith & & & (Delibes de Castro et al. 1986: 33) \\
\hline 18 & Trikualtzi I & 1 & 1 & Megalith & Cretaceous & & (Álvarez Fernández et al. 2005: 166) \\
\hline 19 & Larrate & 1 & 1 & Megalith & Succinite & & (Álvarez Fernández et al. 2005: 166-167) \\
\hline 20 & Gorostiarán E & 1 (lost) & & Megalith & & & (Álvarez Fernández et al. 2005: 167) \\
\hline 21 & $\begin{array}{l}\text { Sepulcro tumular } \\
\text { de Fossa del } \\
\text { Gegant }\end{array}$ & 1 & & Megalith & & & (Rovira i Port 1994: 69, 71) \\
\hline 22 & $\begin{array}{l}\text { Los Millares } \\
\text { VII/7 }\end{array}$ & 4 & & Tholos & & & (Almagro and Arribas 1963: 129) \\
\hline 23 & Los Millares 12 & $\begin{array}{l}5 \text { and a } \\
\text { fragment }\end{array}$ & & Megalith & & & (Almagro and Arribas 1963: 129) \\
\hline 24 & $\begin{array}{l}\text { Los Millares } \\
\text { III/63 }\end{array}$ & 3 & 2 & Megalith & & $\begin{array}{l}\text { Yellow } \\
\text { mica }\end{array}$ & (Almagro and Arribas 1963: 118) \\
\hline 25 & $\begin{array}{l}\text { Los Millares } \\
\quad \text { XIII } / 74\end{array}$ & 1 & & Megalith & & & (Almagro and Arribas 1963: 87) \\
\hline 26 & Los Millares IV/8 & fragment & & Megalith & & & $\begin{array}{l}\text { (Leisner and Leisner 1943: 11, tafel 24; } \\
\text { Almagro and Arribas 1963: 119) }\end{array}$ \\
\hline 27 & Montelirio tholos & $>251$ & $131^{\mathrm{d}}$ & Tholos & Simetite & Simetite & $\begin{array}{l}\text { (Fernández Flores and Aycart Luengo 2013: } \\
\text { 249; Murillo-Barroso 2016), this paper }\end{array}$ \\
\hline 28 & $\begin{array}{l}\text { PP4 Montelirio } \\
10.042-10.049\end{array}$ & $>3$ & 1 & Tholos & Simetite/doubtful ${ }^{\mathrm{e}}$ & & $\begin{array}{l}\text { (Murillo-Barroso and Martinón-Torres 2012: 194-195; } \\
\text { Murillo-Barroso and García Sanjuán 2013; Murillo-Barroso } \\
\text { 2016: 325) }\end{array}$ \\
\hline 29 & Bela Vista & $1\left(\operatorname{lost}^{\mathrm{f}}\right)$ & & Tholos & & & (Vilaça et al. 2002: 74) \\
\hline 30 & $\begin{array}{l}\text { Sepulcro } \\
\text { de la Pera }\end{array}$ & 1 & & Megalith & & & (Rovira i Port 1994: 72) \\
\hline 31 & $\begin{array}{l}\text { Sepulcro tumular } \\
\text { de Cabana } \\
\text { del Moro de } \\
\text { Colomera }^{\mathrm{h}}\end{array}$ & 5 fragments & & Barrow & & & (Rovira i Port 1994: 70) \\
\hline 32 & $\begin{array}{l}\text { Sepulcro tumular } \\
\text { I de El Bosc }\end{array}$ & 19 & & Barrow & & & (Rovira i Port 1994: 70-71) \\
\hline 33 & & & & Barrow & & & (Rovira i Port 1994: 70) \\
\hline
\end{tabular}


Table 1 (continued)

\begin{tabular}{|c|c|c|c|c|c|c|c|}
\hline No. & Site & \# & \# & Context & FTIR & This paper & Reference \\
\hline & $\begin{array}{l}\text { Sepulcro tumular } \\
\text { del Collet }^{\mathrm{g}}\end{array}$ & $\begin{array}{l}\text { Some } \\
\text { fragments }\end{array}$ & & & & & \\
\hline 34 & Cova del Frare & 1 & & Cave & & & (Rovira i Port 1994: 72-73) \\
\hline 35 & $\begin{array}{l}\text { Anta do Vale } \\
\text { das Antas }\end{array}$ & $\mathbf{0}^{\mathrm{i}}$ & & Megalith & & & (Vilaça et al. 2002: 74) \\
\hline 36 & $\begin{array}{l}\text { Anta Grande } \\
\text { da Comenda } \\
\text { da Igreja }\end{array}$ & 5 & 2 & Megalith & & Simetite & $\begin{array}{l}\text { (Ferreira 1966; Vilaça et al. 2002: 75), } \\
\text { this paper }\end{array}$ \\
\hline 37 & $\begin{array}{l}\text { Monumento } 3 \\
\text { de Alcalar }\end{array}$ & 5 & 5 & Tholos & & Simetite & $\begin{array}{l}\text { (Ferreira 1966; Vilaça et al. 2002: 75), } \\
\text { this paper }\end{array}$ \\
\hline 38 & $\begin{array}{c}\text { Monumento } 4 \\
\text { de Alcalar }\end{array}$ & 2 & 2 & Tholos & & Simetite & $\begin{array}{l}\text { (Ferreira 1966; Vilaça et al. 2002:75), } \\
\text { this paper }\end{array}$ \\
\hline 39 & Caño Ronco & $\begin{array}{l}\text { fragments } \\
\quad(\text { lost })\end{array}$ & & Megalith & & & (Cabrero García 1985: 3) \\
\hline 40 & Los Delgados I & 1 (lost) & 1 & Megalith & Not-defined & Simetite & (Cabrero García 1988: 46) \\
\hline 41 & Quinta do Anjo & $1^{\mathrm{k}}$ & & $\begin{array}{l}\text { Artificial } \\
\text { Cave }\end{array}$ & & Quartz & (Berdichewsky Scher 1964: 51-53) \\
\hline 42 & $\begin{array}{l}\text { Valle de las } \\
\text { Higuera } 1\end{array}$ & $?$ & 1 & $\begin{array}{l}\text { Artificial } \\
\text { Cave }\end{array}$ & Non-Baltic & Simetite & (Bueno Ramírez et al. 2005: 74) \\
\hline 43 & $\begin{array}{l}\text { Valle de las } \\
\text { Higueras } 3\end{array}$ & $?$ & 1 & $\begin{array}{l}\text { Artificial } \\
\text { Cave }\end{array}$ & Non-Baltic & Simetite & (Bueno Ramírez et al. 2005: 76) \\
\hline 44 & $\begin{array}{l}\text { Cova de la } \\
\text { Pastora }^{1}\end{array}$ & 3 & & Cave & Cretaceous & $\begin{array}{l}\text { Spectrum } \\
\text { not } \\
\text { available }\end{array}$ & (García-Puchol et al. 2012: 284, 286) \\
\hline 45 & $\begin{array}{c}\text { Blanquizares } \\
\text { de Lebor }\end{array}$ & 1 & & Cave & & & (Arribas 1953: 89) \\
\hline 46 & $\begin{array}{l}\text { Paraje de } \\
\quad \text { Montebajo E3 }\end{array}$ & 2 & & $\begin{array}{l}\text { Artificial } \\
\text { Cave }\end{array}$ & & & (Lazarich González et al. 2009: 77-80) \\
\hline 47 & Cova de Llidoner & ? & & Cave & & & (García-Puchol et al. 2012: 286) \\
\hline 48 & $\begin{array}{l}\text { Barranco da } \\
\quad \text { Nora Velha } 1^{\mathrm{m}}\end{array}$ & 9 & & Tholos & & & (Viana 1959: 27) \\
\hline 49 & $\begin{array}{l}\text { Dolmen de } \\
\quad \text { la Pastora }\end{array}$ & 1 & & Tholos & & & (Almagro 1962: 20) \\
\hline 50 & $\begin{array}{l}\text { Llano de } \\
\text { la Sabina } 97\end{array}$ & 1 & & megalith & & & (Lorrio 2008: 187, 288) \\
\hline 51 & $\begin{array}{l}\text { Llano de } \\
\text { la Sabina } 99^{\text {n }}\end{array}$ & 1 & & Megalith & & & (Lorrio 2008: 187, 288) \\
\hline 52 & $\begin{array}{l}\text { Llano de } \\
\text { la Teja } 18^{\circ}\end{array}$ & 1 & & Megalith & & & (Leisner and Leisner 1943: 146, Tafel 46) \\
\hline & $\Sigma$ & $>508$ & 153 & & & & \\
\hline \multicolumn{8}{|c|}{ Bronze Age (2nd millennium BCE) } \\
\hline 53 & Cova del Gegant & 6 & 1 & Cave & & Simetite & (Daura et al. 2017: 150), this study \\
\hline 54 & $\begin{array}{l}\text { Cova de la } \\
\quad \text { Roca del Frare }\end{array}$ & 1 & & Cave & & & (Rovira i Port 1994: 73) \\
\hline 55 & $\begin{array}{l}\text { Cova de } \\
\text { les Pixarelles }\end{array}$ & 2 & & Cave & & & (Rovira i Port 1994: 72) \\
\hline 56 & $\begin{array}{l}\text { Sepulcro tumular } \\
\text { de Can Cuca }\end{array}$ & 1 & & Barrow & & & (Rovira i Port 1994: 71) \\
\hline 57 & $\begin{array}{l}\text { Sepulcro tumular } \\
\text { de Bullons }\end{array}$ & $\begin{array}{l}1 \text { and } \\
\text { fragments }\end{array}$ & & Barrow & & & (Rovira i Port 1994:71) \\
\hline 58 & $\begin{array}{l}\text { Cova dels } \\
\text { Muricecs }\end{array}$ & 135 & 4 & Cave & Succinite & & (Murillo-Barroso and Martinón-Torres 2012:194) \\
\hline 59 & Los Lagos I & Fragments & & Tholos & Cretaceous & & (Álvarez Fernández et al. 2005: 167) \\
\hline 60 & $\begin{array}{l}\text { Sepulcro tumular } \\
\text { de Pedra } \\
\text { Cabana }\end{array}$ & 2 fragments & & Barrow & & & (Rovira i Port 1994: 70) \\
\hline 61 & Monte da Pena & 2 & 2 & Site & & Quartz & (Thomas 2014: 201-202; Fig. 85) \\
\hline 62 & Pragança & 2 & 2 & Site & & Succinite & (Vasconcellos 1895; Gonçalves 1997: 38-39) \\
\hline 63 & $\begin{array}{l}\text { Cueva de } \\
\text { las Ventanas }\end{array}$ & 1 & 1 & Cave & & Succinite & (Riquelme Cantal et al. 2001: 331) \\
\hline 64 & $\begin{array}{l}\text { La Almoloya } \\
\quad(\text { AY-38 tomb) }\end{array}$ & $>1$ & & Site & & & (Lull et al. 2015: 92) \\
\hline & $\Sigma$ & 156 & 10 & & & & \\
\hline \multicolumn{8}{|c|}{ Long term use } \\
\hline 65 & & 0 & & Site & & & \\
\hline
\end{tabular}


Table 1 (continued)

\begin{tabular}{|c|c|c|c|c|c|c|c|}
\hline No. & Site & $\#$ & $\#$ & Context & FTIR & This paper & Reference \\
\hline & $\begin{array}{l}\text { Atalaião / Atalaia } \\
\text { dos } \\
\text { Sapateiros }^{\mathrm{p}}\end{array}$ & & & & & & (Vilaça et al. 2002: 74) \\
\hline 66 & Alcarapinha $^{\mathrm{q}}$ & 0 & & Site & & & (Ferreira 1966) \\
\hline 67 & $\begin{array}{l}\text { Cova de } \\
\text { Can Mauri }\end{array}$ & 1 & & Cave & & & (Rovira i Port 1994: 70) \\
\hline \multirow[t]{2}{*}{68} & Cova del Garrofet & ? & & Cave & & & (Rovira i Port 1994: 73) \\
\hline & $\Sigma$ (total) & $>697$ & 168 & $24 \%$ & & & \\
\hline
\end{tabular}

${ }^{a}$ According to Angelini and Bellintani (2016) the spectrum of this sample totally differs from that of simetite reference spectrum. They state that, the characterization as simetite has to be considered at least doubtful due to the presence of two strong bands at $c .1000 \mathrm{~cm}^{-1}$ that are lacking in the simetite reference spectra

${ }^{\mathrm{b}}$ No mention of amber beads at La Encantada 3 is made prior to Molina Fajardo and Cámara Serrano (2009) in either (Leisner and Leisner 1943, b; Almagro and Arribas 1963; Lorrio 2008). Unless Molina Fajardo and Cámara Serrano have seen the bead, which they do not explicitly state, it must be considered a mistake

${ }^{\mathrm{c}}$ This is a 4th millennium BCE megalith that was in use during the 3rd and 2nd millennia BCE. It was referenced as La Lora in Álvarez Fernández et al. (2005)

${ }^{\mathrm{d}}$ During the writing of this paper, a recent book has been published analyzing 32 beads from Montelirio tholos (Murillo-Barroso 2016)

${ }^{\mathrm{e}}$ According to Angelini and Bellintani (2016) the spectrum of this sample differs from that of simetite reference spectrum. They state that, the characterization as simetite is not totally certain due to the presence of absorption peaks at about 1000 and $888 \mathrm{~cm}^{-1}$

${ }^{\mathrm{f}}$ There is a bead that resembles amber in its color and texture that is not amber deposited in the Museu Geologico (Lisbon)

${ }^{g}$ Dated to Middle Bronze Age, c. 1800-1500 BCE, by Rovira i Port (1994: 78), Murillo Barroso and Martinon Torres (2012: 203, Table 1) includes it under Chalcolithic/Bronze Age (third to second millennia BC)

${ }^{\text {h }}$ Dated to Middle Bronze Age, c. 1800-1500 BCE, by Rovira i Port (1994: 78), Murillo Barroso and Martinon Torres (2012: 203, Table 1) includes Cabana del Moro de Colomera under Bronze Age (Second millennium BC)

'Silva records a 'callaite' bead found in the chamber (Horta Pereira 1970). This bead still remains deposited in the Mação museum, where Sara Cura, curator of the museum, assures that the bead is referred to by Vilaca (2002) as amber mistakenly

${ }^{\mathrm{j}}$ The sites referred to as Alcalá 3 and 4 in Murillo-Barroso and Martinon-Torres (2012), Lorrio (2008) and Leisner and Leisner 1943 are Alcalar 3 and 4. Alcalá is the nineteenth century spelling of Alcalar

${ }^{\mathrm{k}}$ Neither Leisner (1965) nor Zbyszewski and Veiga Ferreira (1958) nor Soares (2003) refer to amber beads for any of the artificial caves of Quinta do Anjo. However Berdichewski (1964) claims that Belchior da Cruz (1906) records in its inventory several amber beads in cave 4. However, this is a mistake that has been reproduced since Berdichewski's work as no amber bead is recorded in Belchior da Cruz (1906) and no amber bead is deposited in the Museu Geológico (Lisbon). There is, however, a yellowish translucent bead in the loose material assemblage that to an inexperienced eye could resemble amber and that is recorded by Soares (2003) as quartz

${ }^{1}$ Possesses 12 radiocarbon dates in the 4th to 3rd millennia BCE (McClure et al. 2010) without association with individuals or beads

${ }^{\mathrm{m}}$ There is no published record for the amber finds at Barranco de Nora Velha. Consequently, the date of this amber is uncertain, however the material recorded and the monument's architecture advise to ascribe this amber to the 3rd millennium BCE with due care (Martins 2014: 37-38; Sousa 2016)

${ }^{\mathrm{n}}$ The amber piece registered in the Museo Nacional de Arqueología (Madrid) as pertaining to Llano de la Sabina 99 is not cited in the Leisners' review (Leisner and Leisner 1943)

${ }^{\circ}$ We think that the Llano de la Sabina 99 amber bead deposited in the MAN must correspond to this megalith, the only one mentioned in the referred work (Leisner and Leisner 1943) and not included in other works

${ }^{\mathrm{p}}$ We have revised the material from Atalaia dos Sapateiros deposited in the Museu de Vila Viçosa and we could not find any amber bead. What we found are the so-called carnelian beads, typical of Late/Final Bronze Age

${ }^{\mathrm{q}}$ Ferreira (1966) did not find amber beads from Alcaparica deposited in the Museu de Vila Viçosa, neither did the Leisners, and nor did we. What we found are the so-called carnelian beads, typical of Late / Final Bronze Age. These items could be what Viana (cited by Ferreira 1966) might have identified as amber

\section{Anta Grande da Comenda da Igreja}

Anta Grande da Comenda da Igreja, Montemor-o-Novo (CNS 616), is a megalithic monumental passage grave, with collective burials, in use from the late 4th millennium BCE to the first half of the 3rd millennium BCE (OxTL-169f: $3235 \pm 310$; (Whittle and Arnaud 1975: 7)). Its architecture consists of a polygonal chamber $(4.5 \mathrm{~m}$ in diameter and $6 \mathrm{~m}$ in height) formed by eight orthostats and a long passage $c$. $10 \mathrm{~m}$ long in two sections: the first section consists of small orthostats and may have functioned as an atrium; the second section is formed by larger orthostats than those in the previous section. The mound is preserved up to $c .3 .5 \mathrm{~m}$ in height. 
Fig. 1 Studied beads from Anta da Capela

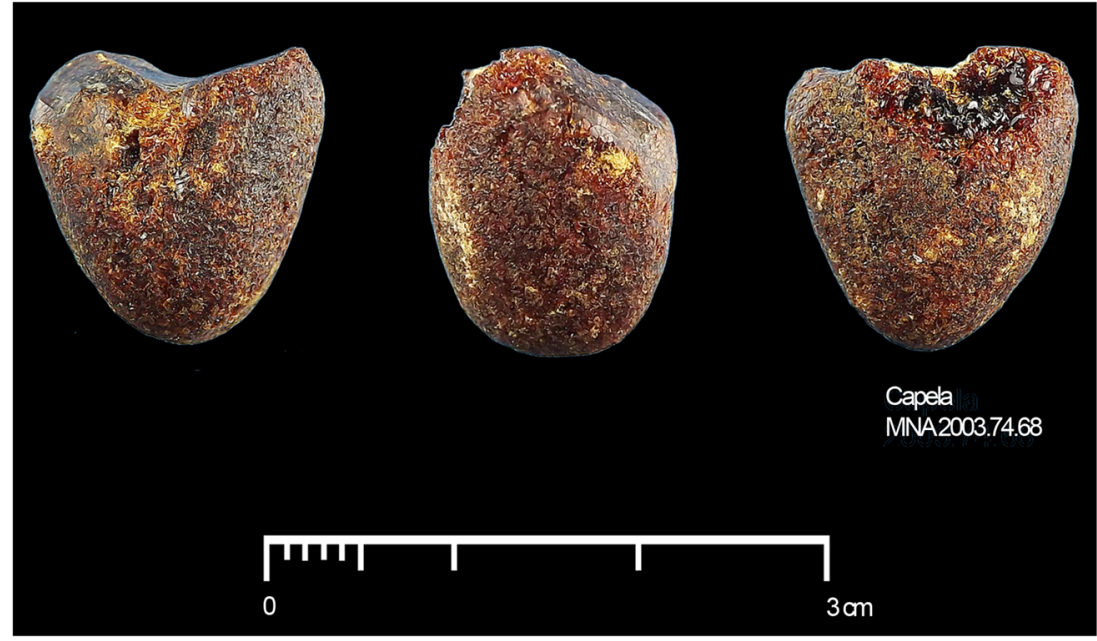

First excavated in the late nineteenth century by Vasconcellos (Machado 1964; Carreira 1995), it has been the object of several excavations in the course of the twentieth century, performed by Heleno in the 1930s (Rocha 2005) and Varela Gomes in the 1980s.

The recovered pottery assemblage is typical of the Iberian 3rd millennium BCE, with small carinated bowls, cups and plates. The excavations also recovered polished stone tools (axes and adzes), some bladelet cores in flint and hyaline quartz, several flint blades, microliths (mainly trapezoids), a set of c. 200 arrowheads shaped from different raw materials and in very diversified typologies (including types typical of the Portuguese Estremadura, like the mitriform and "Eiffel Tower" types), flint halberds and daggers, several dozen engraved schist plaques, sandstone plaques, engraved schist crosses, bone "hair-pins", and a set of beads of different shapes made from various raw materials, including a zoomorphic schist pendant, a blue glass bead (possibly Bronze Age), green beads (talc, muscovite and variscite), lignite beads, fluorite beads (one of them with reticulated decoration) and several amber beads of different typologies (MNA 985.52.1, 2000.21.5 and 2011.54.102) (Fig. 2).

\section{Montelirio tholos}

Montelirio tholos was discovered in 1998 (Fernández Flores and Aycart Luengo 2013; Fernández Flores et al. 2016). Itis located in the necropolis of Valencina de la Concepción settlement, one of the largest (c. 450 ha) and most remarkable sites in Copper Age Iberia (for a detailled review of the site see García Sanjuán 2013; or García Sanjuán et al. 2017).

Architecturally, Montelirio is a tholos with a double chamber oriented on an east-west axis with a total extension of $43.75 \mathrm{~m}$. The corridors' sides as well as the chambers and the main corridor's roofing were made of slate slabs, while the roofing of the two chambers was built with sun-dried mud (Fernández Flores and Aycart Luengo 2013; Fernández Flores and García Sanjuán 2016).

Anthropological studies have revealed a total minimum number of 25 individuals buried in this tholos, 20 in the large chamber, two in the small one and three in the corridor. The individuals buried in the chambers were found to be associated with an extraordinary set of sumptuous grave goods, the most notable of which is an unspecified number of shrouds, cloaks or clothes similar to that of the warrior princes in the Italian Orientalizing period (Negroni Catacchio 2007, 2011), made of hundreds of thousands of perforated beads and decorated with amber beads (DíazGuardamino et al. 2016; Murillo-Barroso 2016). Other remarkable objects include rock crystal arrowheads, blades and a prismatic core, flint arrow heads with long lateral appendices, four fragments of gold blades, ivory objects... (for a detailled review of the monument and its findings the reader is referred to Fernández Flores et al. 2016).

In terms of chronology, 22 C14-AMS dates are available (Fernández Flores and Aycart Luengo 2013; Bayliss et al. 2016). All the calibrated dates lie roughly within the first half of the third millennium BCE. These dates aim to cover from the base level of the large burial chamber to the last individual buried in this chamber, and the burial layer in the smaller chamber. These dates were the subject of debate (Mederos Martín 2013) and recently of pioneering and impressive Bayesian modelling (Bayliss et al. 2016: 493) which shows that the monument was most likely built and used during 2900-2800 cal BCE.

However, these are not the only amber finds in the necropolis of Valencina de la Concepción; Tholos 10.04210.049 from the PP4-Montelirio (Mora Molina et al. 2013) yielded a pommel made of simetite and a bead (Murillo-Barroso and Martinón-Torres 2012; Murillo- 
Fig. 2 Studied beads from Anta Grande da Comenda da Igreja

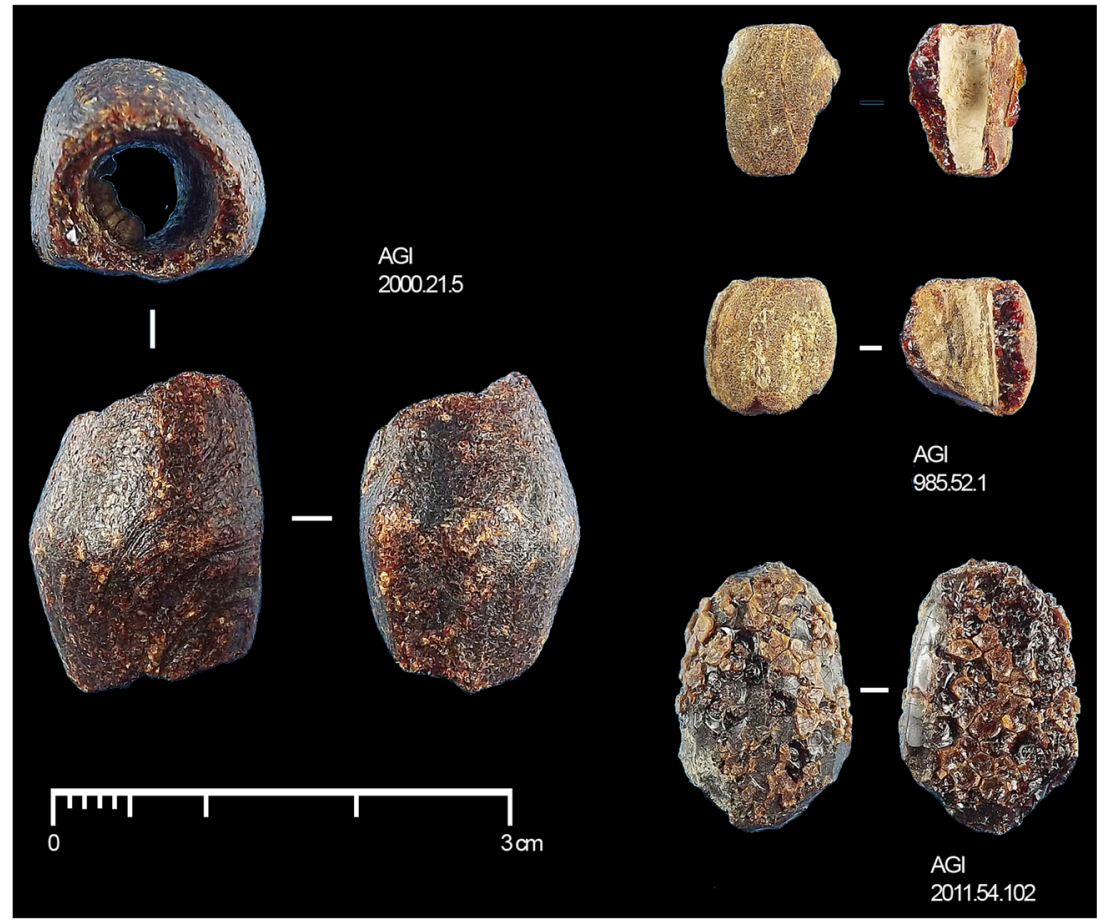

Barroso and García Sanjuán 2013; Murillo-Barroso 2016: 194-195) and La Pastora tholos an amber bead (Almagro 1962: 20) that is deposited in the Museo Arqueológico Nacional in Madrid (although the Museum did not grant permission to analyze the bead when it was applied for).

\section{Monte da Pena/Povoado da Pena/Tholos do Barro}

Monte da Pena hill at Torres Vedras is the location of a corbelled vault tholos-type funerary monument known as Tholos do Barro (CNS 662). Its discovery and first excavation by Bovier-Lapierre, Jalhay and Pereira took place in 1908 (Pereira 1909). It was not, however, until 1965 that the floor-plan of this monument was first drawn by the Leisners (Leisner 1965). Despite the designation of the tholos as a National Monument, the surroundings of it were being used as stone quarry, which moved Trindade to collect the archaeological material found in 1965 and 1972 (Madeira et al. 1972).

Architecturally, Tholos do Barro consists of a 6 m-diameter corbelled vault chamber and a wall-type corridor (Sousa 2016). Its position on the top of a hill is unusual for megalithic monuments. This kind of location has, however, been recorded for other monuments, like Tholos do Monge (Boaventura 2009).

Fieldwork at this monument is deficiently recorded. However, it is most likely that the interior of the monument was completely excavated in 1908 (Pereira 1909) and the subsequent material recoveries were made in the surroundings. This may explain the duality of its naming as Tholos do Barro and Monte da Pena (surroundings of the tholos). Little is known about the surroundings of the tholos. Madeira et al. (1972) points out that this area may have been used as a funerary space, while Schubart referred to it as a settlement (Schubart 1967).

The beads analyzed here (Figs. 3 and 4) were recovered by Trindade and deposited in the Museu Municipal Leonel Trindade and labelled as Monte da Pena. It is most likely that these beads were recovered in the area around the monument, and therefore refer to the Bronze Age necropolis.

\section{Anta Grande de Zambujeiro}

Architecturally, Anta Grande do Zambujeiro (CNS 62) is a monumental megalith with a long corridor $(8.8 \mathrm{~m} \times 2.8 \mathrm{~m})$, and a seven-orthostat polygonal chamber $(5.7 \mathrm{~m} \times 5.5 \mathrm{~m})$ with slab roofing. At the end of the corridor, just before the chamber, a pillar supports the roofing (Soares and SIlva 2010: 97-99). The entrance to the monument was preceded by an atrium and an enormous granite stele / standing stone. The mound possesses a perimeter ring $c .50 \mathrm{~m}$ in diameter and $9 \mathrm{~m}$ high.

The first excavation was performed in Anta Grande do Zambujeiro by Henrique Leonor Pina in 1964-1968 but unfortunately it remains unpublished and no contextual information is available for the finds. Further excavations have recently been made in the tumulus (Santos 2009: 74; Soares and SIlva 2010).

Inside the chamber, the presence of microliths, variscite beads (Odriozola et al. 2012) and polished stone tools 
Fig. 3 Selection of studied beads from Montelirio

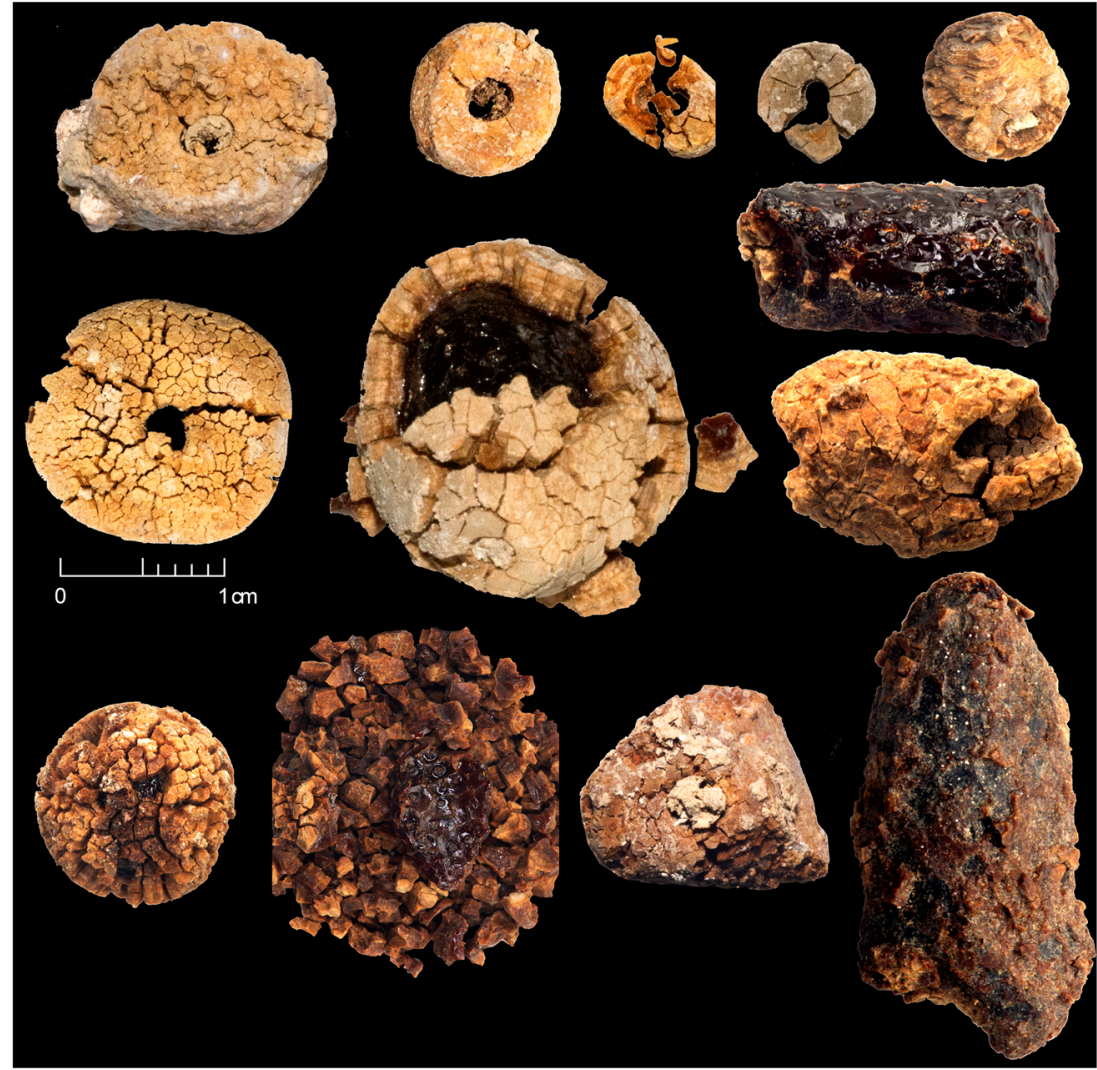

seems to date the first burials in the late 4th millennium BCE (Santos 2009: 62). These older levels were sealed by a fallen chamber slab overlain by a long 3rd millennium $\mathrm{BCE}$ occupational sequence. The most significant burial goods on top of this fallen slab are small decorated pottery vessels (Santos and Rocha 2015), arrowheads, engraved schist plaques, a gold foil and the amber beads (Fig. 5).

The amber beads studied here (Fig. 3) are in an advanced state of oxidation and their surfaces have started to flake (Fig. 6). Despite their state of preservation, the beads form one of the largest amber assemblages for the Iberian Copper

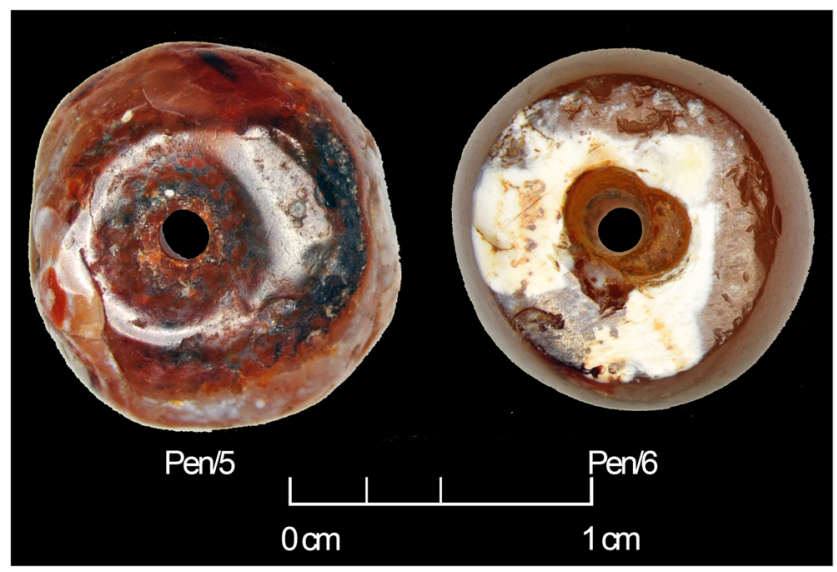

Fig. 4 Studied beads from Monte da Pena
Age with 168 beads/fragments ${ }^{1}$ with a total weight of $c$. $500 \mathrm{~g}$ and some of the largest beads known in the Iberian Peninsula; up to $8 \mathrm{~cm}$ in diameter, $5.6 \mathrm{~cm}$ in height and $54 \mathrm{~g}$ in weight (Table 2). In spite of the difference in number with amber beads from Montelirio tholos, the total weight of both assemblages is very similar. Therefore, they must both be given the same consideration in terms of social significance.

Chronologically, a radiocarbon date obtained from charcoal recovered in the tumulus excavations has given a calibrated date for the megalith that roughly spans the second half of the 3rd millennium BCE (Soares and SIlva 2010: 101). However, no further information about the beads' archaeological context or stratigraphic associations are known other than the data given above. However, the dramatic increase in number of amber artefacts during the Copper Age compared with the Neolithic (Murillo-Barroso and Martinón-Torres 2012: 201-205 Table 1), and the notable number and total weight of the Anta Grande do Zambujeiro amber bead assemblage, only paralleled by the Montelirio tholos assemblage (2900 2800 cal BCE), makes it plausible that the amber beads from Anta Grande do Zambujeiro belong to a very similar time. Whatever the case, the similarity between the Montelirio and

\footnotetext{
${ }^{1}$ It is impossible to calculate a minimum number of beads. The collection is heavily degraded and the museum has individualized 168 records that account for beads and fragments.
} 
Fig. 5 Studied beads from Anta Grande de Zambujeiro

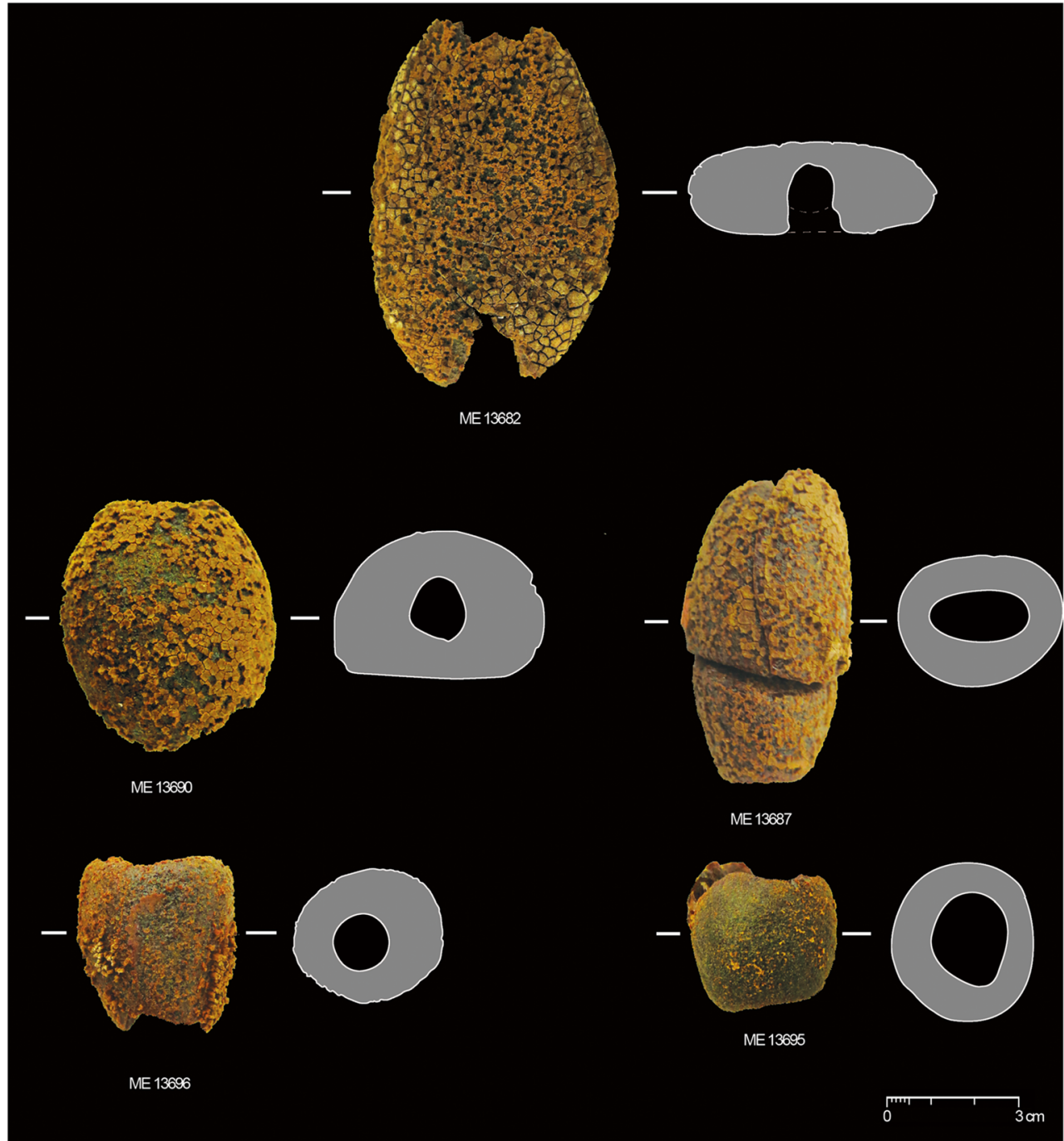

Monuments 3 and 4 at Alcalar

The megalithic cluster of Alcalar, Portimão (CNS 11310, 4298, 3512, 7234, 7241, 7245, 11303, 7249, 7277, 7232,
Fig. 6 Surface detail of the Anta Grande de Zambujeiro beads, showing the high level of degradation

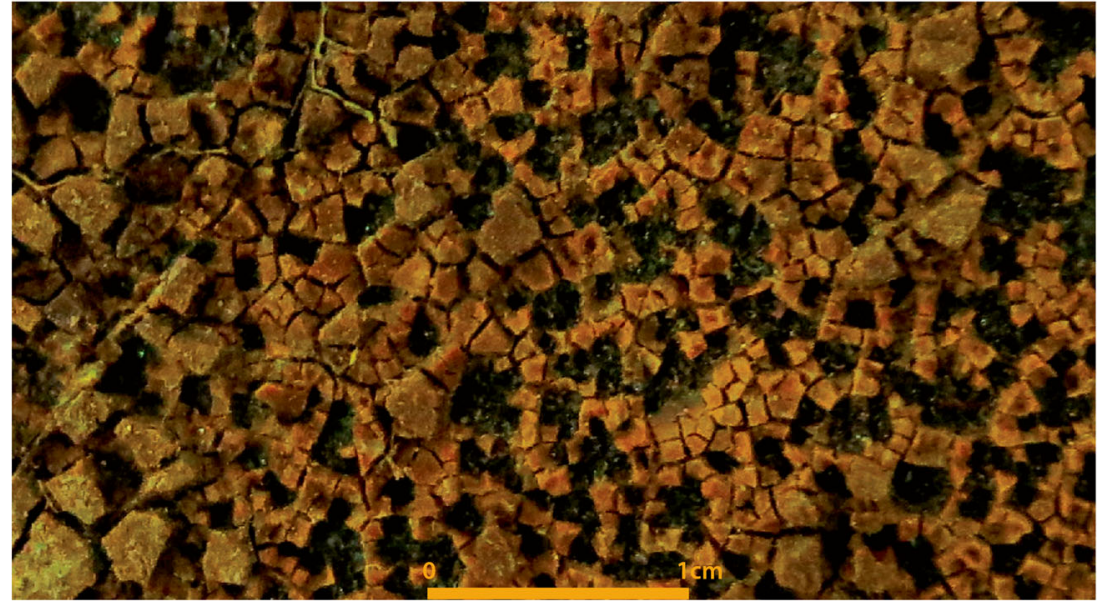


Table 2 Weight of the studied beads

\begin{tabular}{|c|c|c|c|}
\hline \multicolumn{2}{|l|}{ Site } & \multirow{2}{*}{$\frac{\#}{1}$} & \multirow{2}{*}{$\frac{\text { Weight }(\mathrm{g}}{1.33}$} \\
\hline Anta da Capella & MNA 2003.74.68 & & \\
\hline Anta da Capella & $\Sigma$ & 1 & 1.33 \\
\hline Anta Grande da Comenda da Igreja & MNA 985.52 .1 & $1+2$ fragments & $0.32 *$ \\
\hline Anta Grande da Comenda da Igreja & MNA 2000.21.5 & 1 & 1.56 \\
\hline Anta Grande da Comenda da Igreja & MNA 2011.54.102 & 1 & $0.63 *$ \\
\hline Anta Grande da Comenda da Igreja & $\Sigma$ & $>4$ & 2.51 \\
\hline Alcalar 3 & MNA 983.1007 .74 & 1 & 1.66 \\
\hline Alcalar 3 & MNA 983.1007 .75 & 1 & 4.77 \\
\hline Alcalar 3 & MNA 983.1007 .76 & 1 & 3.83 \\
\hline Alcalar 3 & MNA 983.1007 .77 & 1 & $2.37 *$ \\
\hline Alcalar 3 & MNA 983.1007.103 & 1 & 0.48 \\
\hline Alcalar 4 & MNA 983.1008 .113 & 1 & $0.82 *$ \\
\hline Alcalar & $\Sigma$ & 6 & 13.93 \\
\hline Motelirio Tholos & & $>251$ & $>500$ \\
\hline PP4 Monteliro 10.042-10.049 & & $>2$ & - \\
\hline Dolmen de La Pastora & & 1 & - \\
\hline Valencina de la Concepción & $\Sigma$ & $>254$ & $>500$ \\
\hline Anta Granda de Zambujeiro & ME 13682 & 1 & 54.00 \\
\hline Anta Granda de Zambujeiro & ME 13690 & 1 & 36.65 \\
\hline Anta Granda de Zambujeiro & ME 13687 & 1 & 24.10 \\
\hline Anta Granda de Zambujeiro & ME 13696 & 1 & 14.66 \\
\hline Anta Granda de Zambujeiro & ME 13685 & 1 & 7.80 \\
\hline Anta Granda de Zambujeiro & & $>163$ & $>362.80$ \\
\hline Anta Granda de Zambujeiro & $\Sigma$ & $>168$ & $>500$ \\
\hline Pragança & MNA 986.162.2261 & 1 & 3.00 \\
\hline Pragança & MNA 986.164 .6 & 1 & 4.32 \\
\hline Pragança & $\Sigma$ & 2 & 7.32 \\
\hline
\end{tabular}

*Bead is fragmented at c. the half of its size; therefore, the weight of the entire bead should be twice the weighted

$7238,6807,7215,33793,33792$ ) is mainly characterized by a central group formed by 15 monuments, with Alcalar 1 corresponding to a dolmen-type tomb, and the remaining monuments to corbel vault tombs (tholos-type) with different typologies (Gonçalves, 1989; Leisner and Leisner, 1943, 1959; Sousa, 2016; Veiga, 1886, 1889). Other peripheral groups are associated with this central core, such as Monte Velho (three tholoi), Monte Canelas (four hypogea) and Poio (one possible tholos and a natural cave). All these extensive funerary areas are directly associated with an important Chalcolithic settlement, the ditched enclosure of Alcalar (Morán 2014).

The monuments were excavated in the late nineteenth century and during the first half of the twentieth century by Nunes da Glória (Alcalar 1 and 10; Veiga 1886), Estácio da Veiga (Alcalar 2 to 7; Veiga 1889), Pereira Jardim (Alcalar 8 and 9; Rocha 1904), Santos Rocha (Monte Velho 1 to 3; Rocha 1911) and Formosinho (Alcalar 11 to 13; Viana et al. 1953). Since the 1980s, archaeological work in the area of Alcalar has included the re-excavation and restoration of monuments 7 and 9, as well as excavations in the settlement area of Alcalar and in the hypogea of Monte Canelas (Morán and Parreira 2004, 2007).

In general terms, the first moment of use of this area as a funerary space could be established in the last quarter of the 4th millennium BCE, corresponding to the construction and first use of the dolmen of Alcalar 1 and the hypogeum of Monte Canelas 1. It could then be extended throughout the 3rd millennium BCE, with the construction and first use of the corbel vault monuments (possibly still during the first half of the 3rd millennium) and their subsequent reuse (now in the second half).

The amber artefacts studied here (Fig. 7) were collected in monuments 3 and 4 at Alcalar, two tholos-type monuments with different architectural features.

Alcalar 3 (Veiga 1889: 131-250) corresponds to a monument included in a mound of about $20 \mathrm{~m}$ in diameter. The passage, divided into three sections (with atrium and 
Fig. 7 Studied amber items from Alcalar 3 and 4

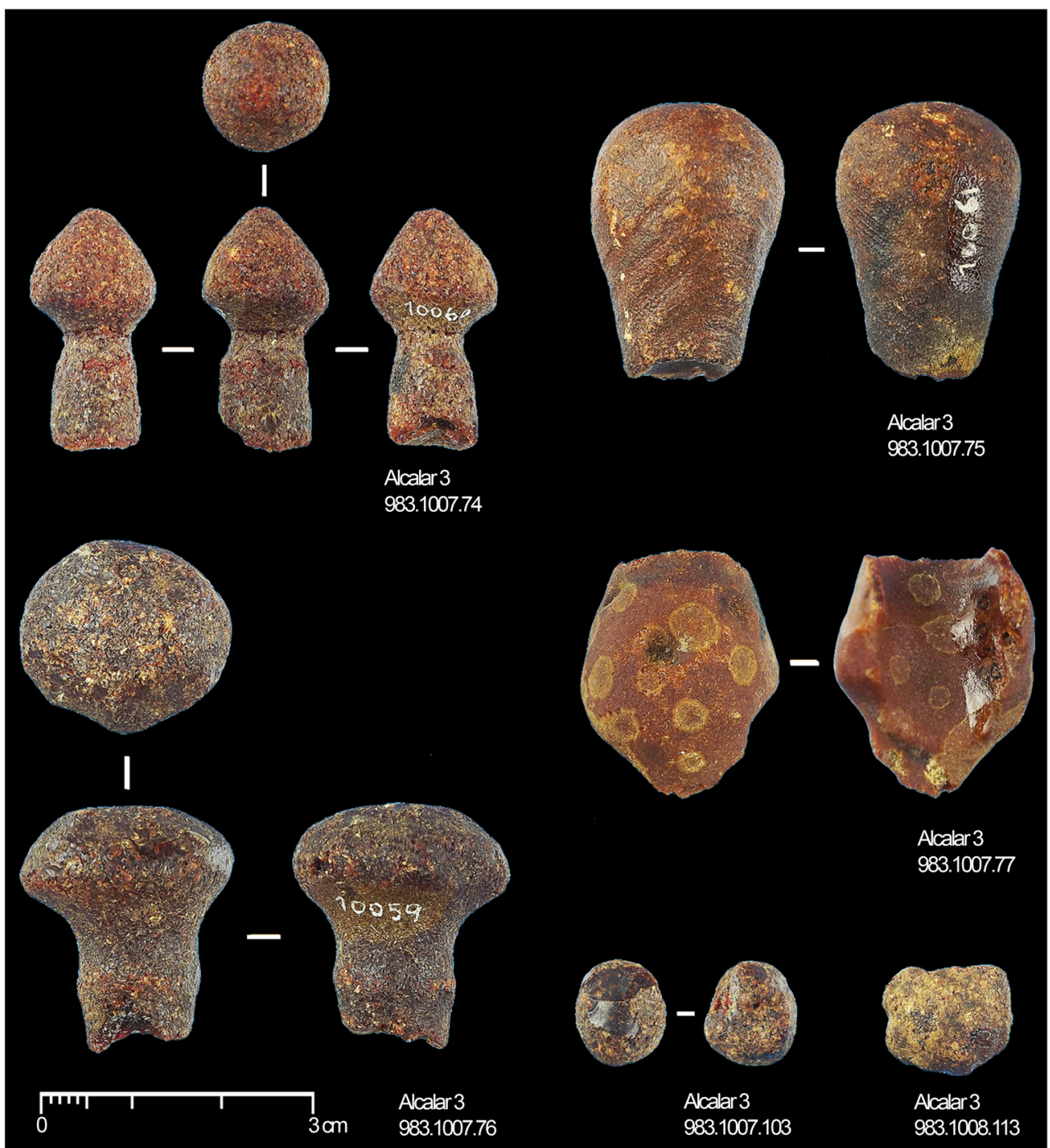

antechamber), is about $6.10 \mathrm{~m}$ long, orientated towards the SE and formed by narrow vertical slabs. The chamber, about $2.80 \mathrm{~m}$ in diameter, is also formed by vertical slabs on which the base of the dome would be supported. It has a niche on the NE side of the Chamber, about $0.75 \mathrm{~m}$ above its base.

The artefact assemblage, distributed in the chamber and the passage, includes stone axes (sparse and fragmented), fragments of flint blades, flint cores, concave-base arrowheads, a grindstone and its "pestle", and limestone "mortars" (one of them with traces of red pigment inside). The adornment elements include a bone "hair pin" rod and various green stone and slate beads. Several potsherds (including a plate with "almond-shaped" rim and red slip on its surfaces) and an ivory "plaque" were also collected.

Particularly interesting is the artefact set collected in the lateral niche of the chamber, associated with a set of human bones indicating a secondary deposition of a possibly male individual. This set includes seven large flint blades (two of them corresponding to crested elements) and several copper artefacts (two knives, five daggers with lateral notches for attachment to the handle, three axes, an awl, two chisels, two "plaques" of indeterminate use and a "band" about $70 \mathrm{~cm}$ in length with terminal spurs for fixation).

Alcalar 4 (Veiga 1889: 183-226) corresponds to a monument included in a mound of about $20 \mathrm{~m}$ in diameter. The passage, which is about $8 \mathrm{~m}$ in length and oriented towards the SE, has an atrium (marked by two large limestone blocks) and an antechamber, of orthostatic-type, formed by thick slabs (dolmen type). The chamber, about $2.90 \mathrm{~m}$ in diameter, is formed by an integral dome (masonry of slate and sandstone slabs built right from the bottom of the chamber), presenting two niches on the NE and NW sides, about $1 \mathrm{~m}$ above its base.

It provided few votive artefacts, very fragmented and mixed-possibly motivated by violations in Roman times. The recovered assemblage includes straight and concavebase arrowheads, a fragment of an engraved schist plaque, ceramic loom weights, abundant potsherds (over 100 fragments), and green stone and slate beads. Artefacts in ivory 
(two "plaques" and a possible unworked piece), gold (two decorated "foils") and copper (Palmela point) were also recovered.

Although the earliest uses of these monuments could be attributable, with the necessary precautions, to the first half of the 3rd millennium BCE, it is to its second half that the main funerary uses should be reported, as evidenced by the abundant presence of artefacts in copper (mainly in Alcalar 3) and gold. Possibly, the artefacts in ivory and amber are also assignable to this chronological stage.

Only two of the amber artefacts collected in these monuments correspond to beads, namely MNA 983.1007.77 (Alcalar 3) and MNA 983.1008.113 (Alcalar 4). The remaining elements, all from Alcalar 3, refer to a small nodule (MNA 983.1007.103) and three "mushroom-shaped" artefacts (MNA 983.1007.74 to 76). The latter may correspond to dagger hilts, similar (although smaller in size) to the amber knob collected in Valencina de la Concepción, in the funerary structure 10.042-10.049 of PP4-Montelirio (Murillo-Barroso and García Sanjuán 2013).

The presence of these elements in Alcalar 3 is suggestive because, as mentioned above, a considerable set of copper daggers was collected. However, these possible dagger knobs from Alcalar 3 are not apparently associated with the deposition of the daggers (identified in the lateral niche of the chamber). However, they could have been displaced from their original position by post-depositional actions. The presence of ivory "plaques" may also contribute to this hypothesis, as they could correspond to elements also used in the enamelling of daggers.

\section{Cova del Gegant}

Cova del Gegant (Sitges, Barcelona) is a cave located in the Garraf Massif (NE Iberian Peninsula), on the Cape of Punta de les Coves. Cova del Gegant is formed by a subterranean network of galleries, which includes Cova del Gegant and the adjacent Cova Llarga, to which it is connected by a very narrow passage (GL-T). Cova del Gegant is the most important and consists of a main chamber (GP1 + GP2) with a length of $22 \mathrm{~m}$ and two side galleries (GL) almost in parallel, one closer to the sea (GL1) and the other more inland (GL2).

The stratigraphic sequence comprises various layers grouped in 8 episodes, from the Upper Pleistocene (Episodes 0-3), c. 49-60 ka, to the Holocene (Episodes 4-7) (Daura et al. 2010). As regards the Holocene layer, Episode 4 is the oldest (Bronze Age), represented by Levels VI and Ic2 (GP, GL2 sector) and Layer XXV (GP2 sector). Two additional pit-storage structures (Silo-1 and Silo 2) have been documented in the same formation episode. Episode 5 corresponds to an erosive transgression that emptied part of the deposit and accumulated beach sand, corresponding to Level VII, X and XIf (Iron Age - Middle Ages). Episode 6 is the most recent sediment with Layers Ia-f (Roman - Middle Ages -Modern) consistent with the same chronological horizon as Episode 5. Episode 7 corresponds to current sea erosion.

The archaeological layer ascribed to the Bronze Age mainly corresponds to a collective burial radiocarbon dated to the Middle Bronze Age, 1600-1400 cal BCE. The artefacts recovered comprise Late Bell Beaker pottery $(\mathrm{NR}=71)$ featuring a decorative style akin to the Northeastern Group, generally ascribed to the Early Bronze Age. Human remains comprise 1728 bones ascribed to a MNI of 19 , of which three of them have been directly dated. Ornaments are scarce and consist of four shell-beads, three lignite-jet beads, two amber beads (Fig. 8), one coral fragment and one Cypraea fragment. Additionally, two gold artefacts known as tutuli have been recovered from the same archaeological horizon; these are very rare ornaments in the SW of Europe (Daura et al. 2017).

\section{Los Millares}

Los Millares was first excavated by Siret and Flores (Almagro and Arribas 1963) and remained partially unpublished (Siret 1893) until the Leisners (Leisner and Leisner 1943) undertook a complete revision of the materials deposited in the Museo Arqueológico Nacional (Madrid). It was not, however, until Almagro and Arribas' excavations (Almagro and Arribas 1963) that the site was scientifically excavated and published. Lately, in the last decades of the twentieth century, several excavations were performed in the settlement and the necropolis (Arribas Palau et al. 1979, 1981, 1983).

The 84 tombs in Los Millares necropolis (Afonso Marrero et al. 2011) display, according to Chapman (1990), some differentiation in terms of presence/absence of symbolic items and exotica made from rare raw materials such as amber. This results in clusters of tombs that can be related to social differences between clans or family groups. This appreciation raised some criticism and Chapman (2003, 2008) has lately revised his conclusion, minimizing social differences in the Copper Age and placing the emphasis on this in the Bronze Age. However, other authors claim that marked social hierarchization existed during the Copper Age based on the spatial organization of Los Millares necropolis and its grave goods (Afonso Marrero et al. 2011).

There are, however, undeniable problems when dealing with Los Millares grave goods, stemming from the fact that the archaeological record was generated primarily in the late nineteenth century. The most serious problem is uncertainty about the association between grave goods and the tomb from which the item was recovered. To date, only 31 of the tombs excavated by Siret and Flores have been identified definitively (Chapman 1990; Afonso Marrero et al. 2011).

Chronologically, Los Millares covers a time span ranging from the last quarter of the 4th millennium to the early 2 nd millennium BCE. That covers the whole Copper Age period. 


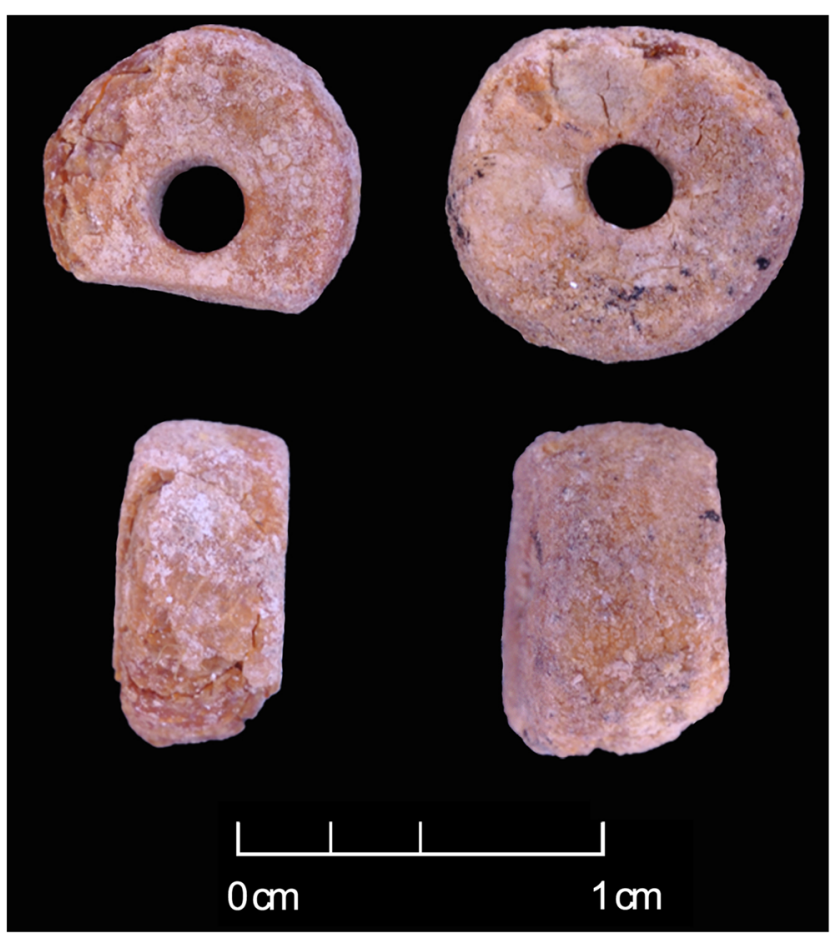

Fig. 8 Studied amber items from Cova del Gegant

A total of 16 amber beads and fragments were recorded in five tombs: VII/7, IV/8, 12, III/63 and 74 (Arabic numerals correspond to the Siret-Leisner seriation and the Roman numerals to that of Almagro and Arribas). Architecturally, the tombs consist of a corridor made of slabs and divided into two sections by a door, and a chamber with a central pillar that would support the dome. The only corbelled chamber is in tomb VII/7, which lacks the central pillar. Unfortunately, Leisner and Siret's works do not record the location of the finds in each tomb.

Tomb 12 yielded five amber beads of different typologies and sizes, and a fragment (Leisner and Leisner 1943: 25, tafel 11). The most remarkable is a large barrel bead (1976/1/ MILL/12/2), $4.7 \mathrm{~cm}$ long and decorated with parallel, incised lines along the perforation that are now inappreciable because of the degradation of the piece $(4.5 \times 2.10 \mathrm{~cm})$. The Leisners (Leisner and Leisner 1943) also describe a bead fragment, two cylindrical amber beads (one with red pigment), a discoidal bead, and a "tear-shaped" amber pendant with V-shaped perforation (Leisner and Leisner 1943: 25, tafel 11).

A non-perforated amber flat-sphere (1976/1/MILL/63/1) was also found during Siret's works in Tomb III/63 (Leisner and Leisner 1943: 11, tafel 24; Almagro and Arribas 1963: 118). Similar examples of non-perforated amber objects have been found in Los Delgados I tomb. Nowadays, both pieces are exhibited in Museo Arqueológico Nacional in Madrid.

An amber bead was found in each of Tombs IV/8 (Almagro and Arribas 1963: 119-122) and 74 (Leisner and Leisner 1943: 24).
Tomb VII/7 is the only tholos of the megalithic tombs at Los Millares that has yielded amber (Almagro and Arribas 1963: 72-74). According to the Leisners' publication, this tomb may have housed at least 50 individuals, and at least 3 amber beads (Leisner and Leisner 1943: 27; tafel 12). However, when Almagro and Arribas studied the Siret collection in the $1950 \mathrm{~s}$, the oxidation process had already reduced the beads to fragments (Almagro and Arribas 1963: 129). We do not know if these fragments are still conserved in the Museo Arqueológico Nacional in Madrid or not as the Museum has denied access to this material. In addition to this, beads from Los Millares studied here (CE00845 and CE00846) (Fig. 9) are described as amber in the CERES catalogue, and were recovered by Almagro and Arribas in tomb VII/7, but no amber beads were said to be found during their excavations (Almagro and Arribas 1963). Instead, they refer to quartz beads.

\section{Cueva de las Ventanas}

Cueva de las Ventanas (Piñar, Granada, Spain) is a natural karst cave located in Sierra Harana, with a long-term use-history from the Upper Paleolithic to the Modern Era. The first archaeological citations to Cueva de las Ventanas are given by H. Obermaier, who visited the cave in 1916 and recorded Neolithic burials and materials already violated by locals. Latterly, J.-Ch. Spahni explored the cave in 1954 in the quest for Paleolithic remains, without any success. During rescue archaeological work under the supervision of Riquelme (Riquelme Cantal et al. 2001: 328), the bead studied here (Fig. 10) was found in association with two 'Argaric' inhumations in the 17-A sector of the cave.

These 'Argaric' Bronze Age burials were found sealed under a stone slab. The burial consisted of an adult found in fetal position on the left side, with only a piece of flint and some goat bones as grave goods. This inhumation was prepared in the place once occupied by a young adult burial, which disturbed most of his bones in the process. The conserved grave goods for this young adult individual were a small polished pebble, a deer calcaneus and an amber bead (Riquelme Cantal et al. 2001: 330-332). This is the only amber find definitely associated with an individual in the Province of Granada for the whole Bronze Age.

\section{Pragança}

Pragança (Cadaval) was discovered in the nineteenth century (Vasconcellos 1895) and excavated by Vasconcellos in 1893 and latterly by Gonçalves in 1988 and 1990 (Gonçalves 1997).

This often-used site was occupied in the Neolithic while materials from the Final Bronze Age, Iron Age and Roman times have also been found. The Copper Age occupation is 
Fig. 9 Studied beads from Los Millares

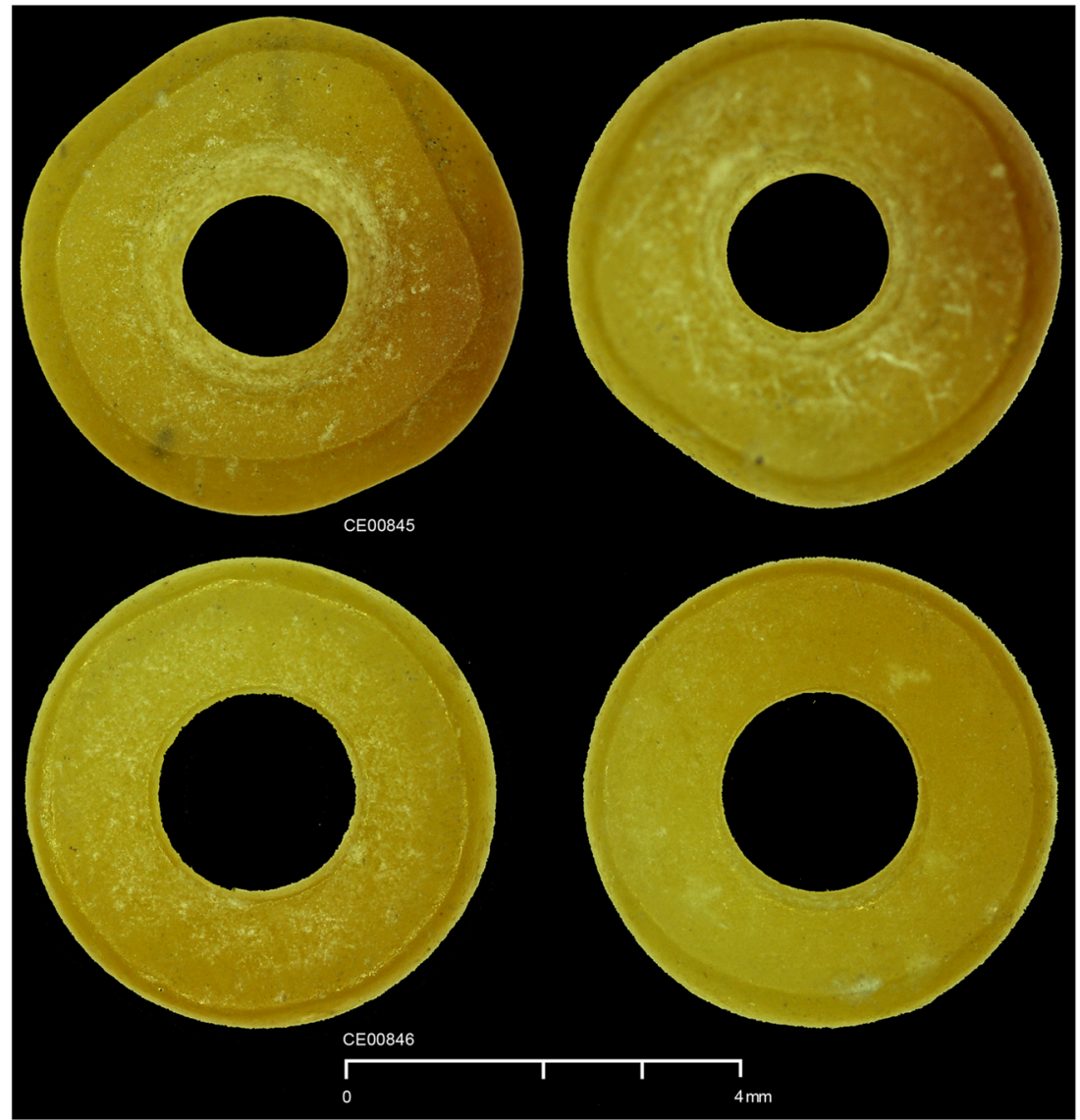

well documented by radiocarbon dates in the first half of the 3rd millennium BCE (Gonçalves 1997). However, the Bronze Age occupation must have been the most important as regards the abundance of metallic finds (Gonçalves 1997).

Many of the finds deposited in the Museu Nacional de Arqueologia are isolated finds from nineteenth century local collectors or Vasconcellos' excavations and no clear record of the amber bead (Fig. 11) studied here is given. Despite the Copper Age radiocarbon dates for this site, it is likely that this amber bead is from the Bronze Age due to 1) its typology, similar to that of Cabecinho de Capitoa (Sousa 2008), Moreirinhos and Senhora da Guia (Vilaça et al. 2002); and 2) the probable association with a Bronze Age metallic personal ornament assemblage (necklace, earring, button...).

\section{Materials and methods}

Since infrared spectroscopy is capable of satisfactorily distinguishing between Sicilian, Baltic, and Iberian Cretaceous ambers, copal... and can be performed either non-destructively, by means of attenuated total reflectance infrared spectroscopy (ATR-FTIR), or on a very small sample of no more than $1 \mathrm{mg}$, it has become the standard technique
Fig. 10 Studied beads from Cueva de las Ventanas

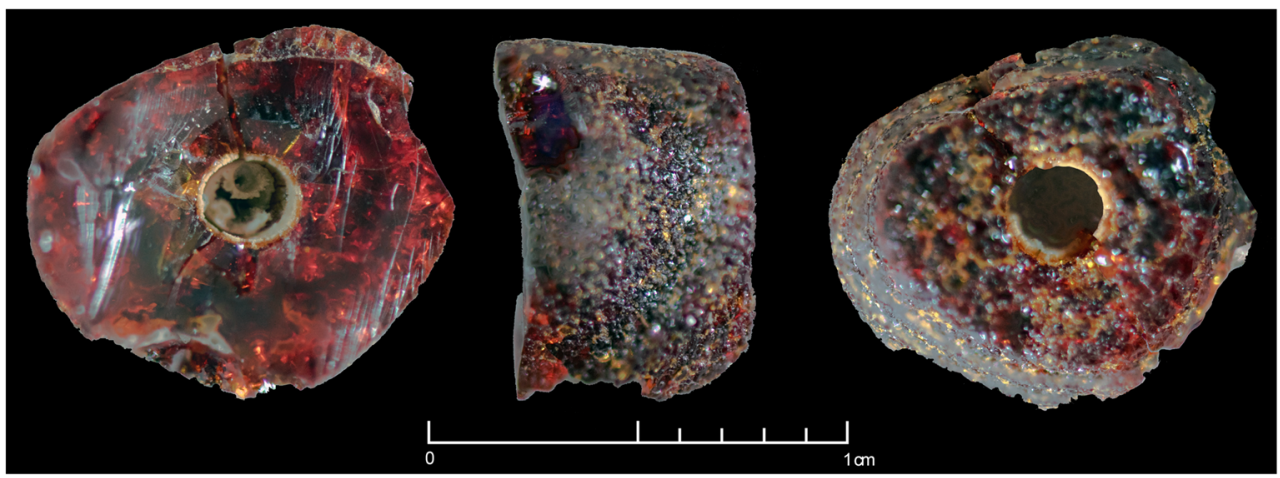


Fig. 11 Studied beads from Pragança

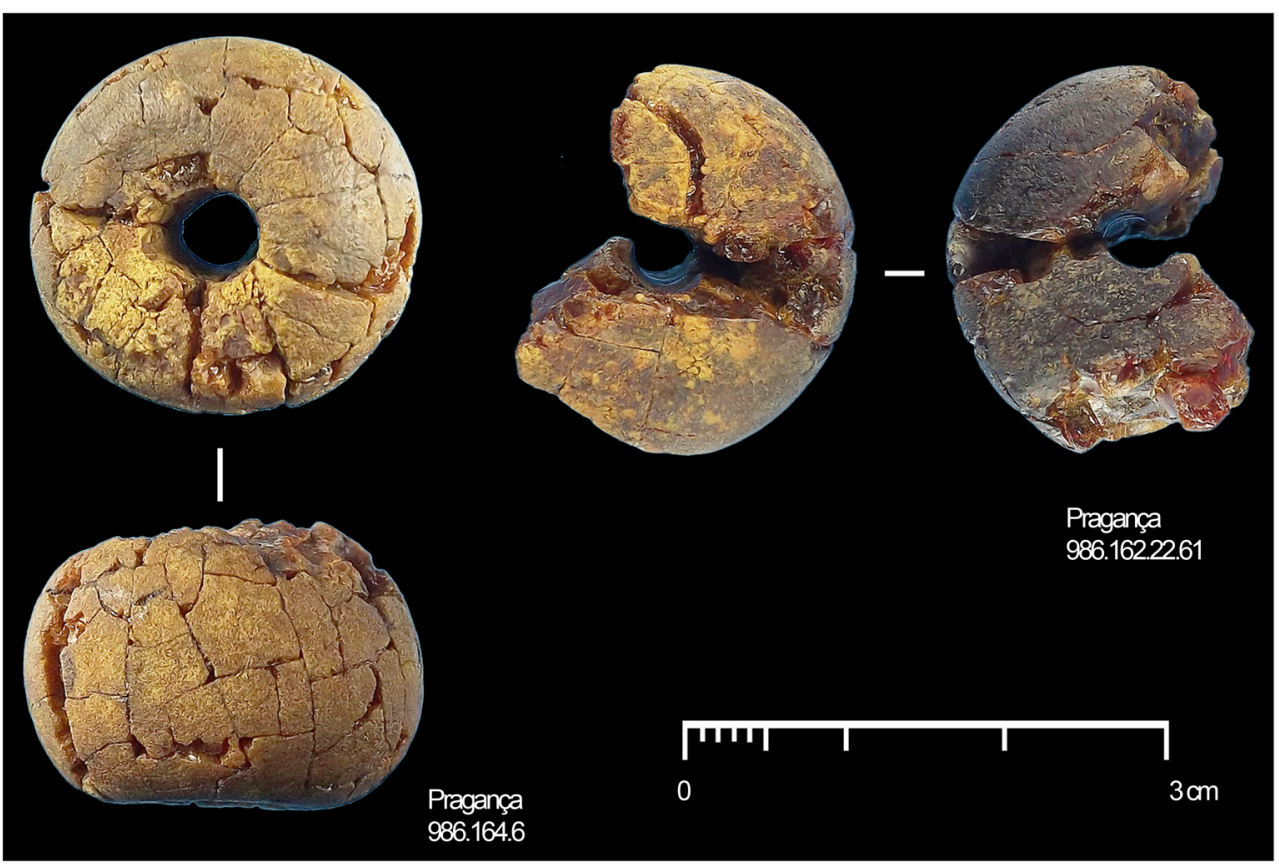

applied in archaeological research to determine the origin of amber artefacts. We have therefore followed this wellgrounded methodology to perform the study of 156 of the $>697$ amber beads found at ten Iberian 6th-to-2nd millennia BCE sites (Table 1), in order to investigate their origins and the internal homogeneity of the amber bead assemblages.

This analytical study was conducted at the Institute for Material Science in Seville (CSIC-University of Seville) laboratories. All sampled beads were tested by Fourier Transform Infrared spectroscopy (FTIR).

Approximately $1 \mathrm{mg}$ of sample was ground by hand using an agate mortar and mixed with a small amount of $\mathrm{KBr}$, before pressing ( $8 \mathrm{~T})$ the mixture to produce discs $1 \mathrm{~mm}$ thick. The specimens were analyzed using a JASCO FT/IR-6200 spectrometer. The data were collected as infrared transmission spectra after scanning each specimen 32 times in the range $4000-400 \mathrm{~cm}^{-1}$, with a resolution of $4 \mathrm{~cm}^{-1}$.

A sample of human bone in direct connection with the bead assemblage from Anta Capela was submitted for AMS-radiocarbon dating, as will be discussed below. Radiocarbon measurements were performed using a $1 \mathrm{MV}$ accelerator mass spectrometer (AMS) at the facilities of the University of Seville (Centro Nacional de Aceleradores). The chemical preparation of the samples followed standard procedures (Santos Arevalo et al. 2009). Collagen extraction from bone tissue followed ultrafiltration protocols to remove low molecular weight contaminants (Higham et al. 2006).

The Anta de Capela date and other available dates for amber-associated contexts are assessed in terms of the development of amber body ornamentation in Iberia.

\section{Results and discussions}

\section{FTIR-based provenance analysis}

\section{Montelirio tholos}

The whole Montelirio tholos bead assemblage yielded similar spectra, probably indicating that all the beads were shaped from the same type of resin. There are, however, exceptions. In Fig. 12, it is possible to observe how some samples fall outside the general trend depicted by the mean spectrum and its standard deviation -15 out of 131 samples.

None of the spectra show the so-called Baltic shoulder - an intense absorption peak in the $1160-1150 \mathrm{~cm}^{-1}$ range, preceded by a characteristic band between 1250 and $1180 \mathrm{~cm}^{-1}$, typical of ambers from the Baltic (Beck et al. 1965). Instead, in the $\mathrm{C}-\mathrm{O}$ stretching region $\left(1300-1000 \mathrm{~cm}^{-1}\right)$, a distinctive $\mathrm{COOH} \mathrm{C-O} \mathrm{stretch} \mathrm{vibration} \mathrm{at} 1238 \mathrm{~cm}^{-1}$ together with a set of absorption bands at $c .1174,1108,1038$ and $976 \mathrm{~cm}^{-1}$ were recorded. Based on the registered FTIR spectra, an Iberian origin for this bead assemblage must be discarded because feature bands recorded for 1 . North Iberian ambers - c. 1020 and $960 \mathrm{~cm}^{-1}$ (Peñalver et al. 2007: 847-848), 2. Puerto del Boyar (Cádiz) — c. 1600, 1450, 1075, and $875 \mathrm{~cm}^{-1}$ (Domínguez-Bella et al. 2001: 627), and 3. Guadalajara amber-c. 1238 and $1174 \mathrm{~cm}^{-1}$ (Cerdeño et al. 2012: 380383)_are missing in the Montelirio tholos samples. Therefore, an Iberian origin for the Montelirio tholos bead assemblage can be rejected.

Archaeological ambers from Iberia have revealed patterns similar to those of simetite, with feature bands at c. 1241 and $1181 \mathrm{~cm}^{-1}$ as well as an absence of an absorption at $890 \mathrm{~cm}^{-1}$. 
Fig. 12 Montelirio tholos bead assemblage FTIR spectra, mean spectra and standard deviation

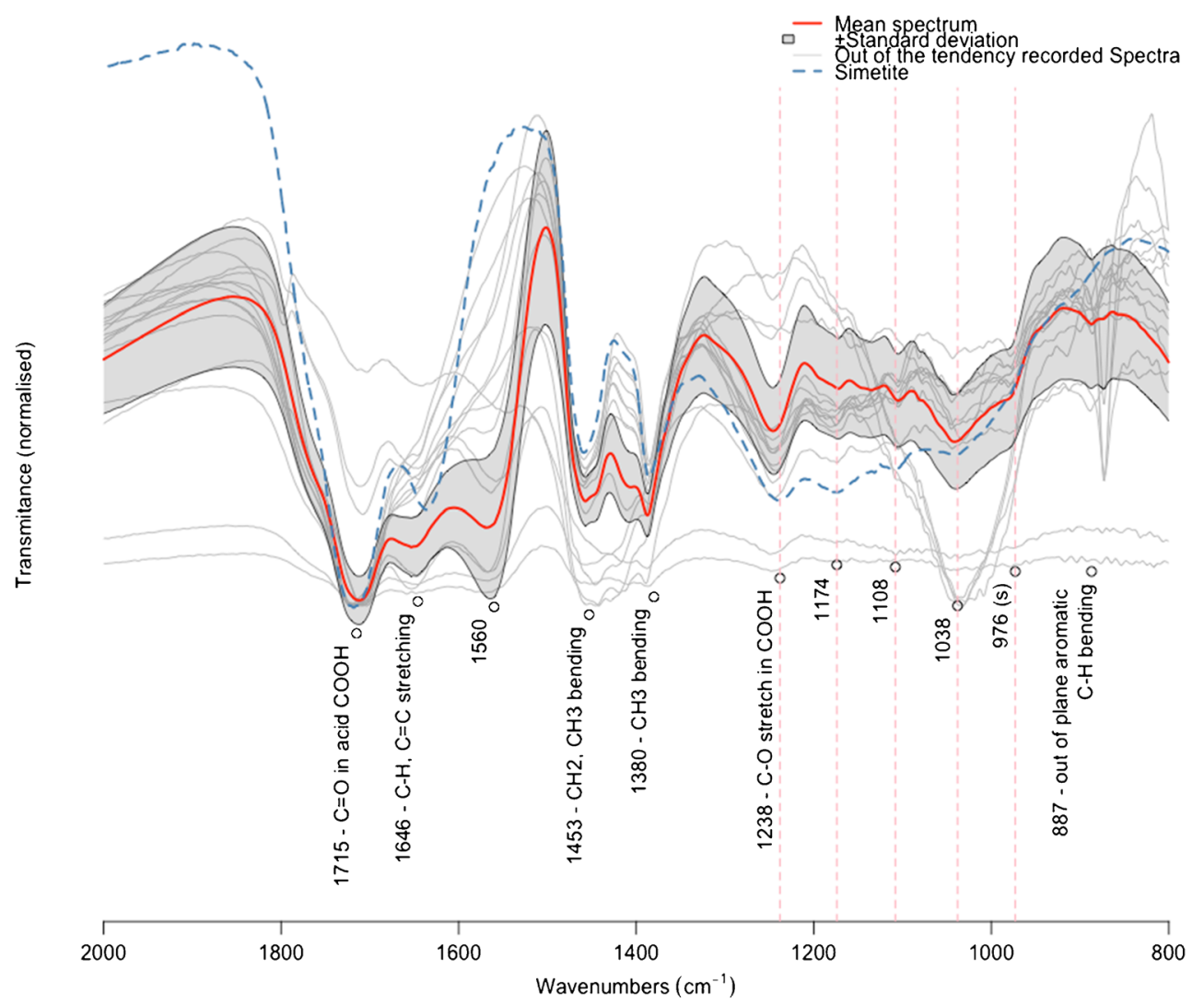

These include the amber from the Neolithic megalithic tombs of Alberite (Domínguez-Bella et al. 2001: 627), Mamoa V (Vilaça et al. 2002: 62), Chousa Nova (Dominguez Bella and Bóveda 2011: 374), and structure $10.042-10.049^{2}$ at the PP4 Montelirio (Murillo-Barroso and Martinón-Torres 2012: 194-195). A Sicilian origin was proposed for the amber beads found in Alberite and structure 10.042-10.049, while Dominguez Bella and Bóveda (2011), Vilaça et al. (2002) and Dominguez Bella (2010) acknowledged the resemblance to simetite for Chousa Nova, Mamoa V and Valle de las Higueras 1 and 3, while highlighting that a local origin from botanical sources similar to the Sicilian simetite should not be rejected. Angelini and Bellintani (2016: 10), whilst admitting its plausibility, have recently questioned the Sicilian origin of the structure 10.042-10.049 amber pommel due to the presence of absorption peaks at about 1000 and $888 \mathrm{~cm}^{-1}$.

Although, the Montelirio tholos mean spectra seem to match the simetite pattern, it does shows a feature band at $c$. $1560 \mathrm{~cm}^{-1}$ (Fig. 13) that is absent from simetite consensus spectrum or any of the reference patterns collected to date (Beck and Hartnett 1993). This band has been recorded in combination with an intense peak at about $1246-1256 \mathrm{~cm}^{-1}$ in archaeological samples from Trinitapoli, Puglia, southern

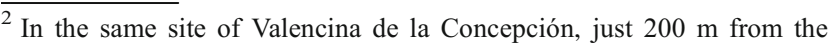
Montelirio tholos.
}

Italy (Angelini and Bellintani 2005), in Valle de las Higueras 1 and 3, Huecas, Toledo (Dominguez Bella 2010) and in highly oxidized samples from Montelirio tholos (Murillo-Barroso 2016: 326-327).

According to Maish et al. (2012), a band at c. $1574 \mathrm{~cm}^{-1}$ may appear in poorly preserved Baltic ambers due to salts of succinic acid. This band has proved to be intense in samples taken from the amber surface, while it is weaker for samples taken from the amber core. This band is believed to be due to alkaline conditions during burial, or harsh cleaning with alkaline chemicals (Pastorelli 2009; Maish et al. 2012). However, carboxylic acid salts are known to show asymmetric $\mathrm{COO}^{-}$ stretching vibrations in the region $c$. $1560-1600 \mathrm{~cm}^{-1}$ (Shevchenko 1963). This may be the case for the Montelirio tholos beads studied here, and the analyzed samples from Trinitapoli and the beads from Valle de las Higueras 1 and 3 were strongly weathered (Angelini and Bellintani 2005; Dominguez Bella 2010).

The asymmetric $\mathrm{COO}^{-}$stretching vibrations recorded for the Tholos de Montelirio sample at c. $1560 \mathrm{~cm}^{-1}$ (Fig. 12) could be related to the presence of succinate salt as a byproduct of degradation processes caused by an alkaline burial environment (soil pH in the burial chamber is c. 8.4-8.3: (Borja Barrera et al. 2010: 18). Consequently, we believe that observed spectral differences at $c .1560 \mathrm{~cm}^{-1}$ within the 131 spectra from Montelirio tholos are due to the deterioration of 
Fig. 13 Montelirio tholos bead assemblage general trend FTIR spectra, mean spectra and standard deviation compared to simetite reference spectrum together with band assignments

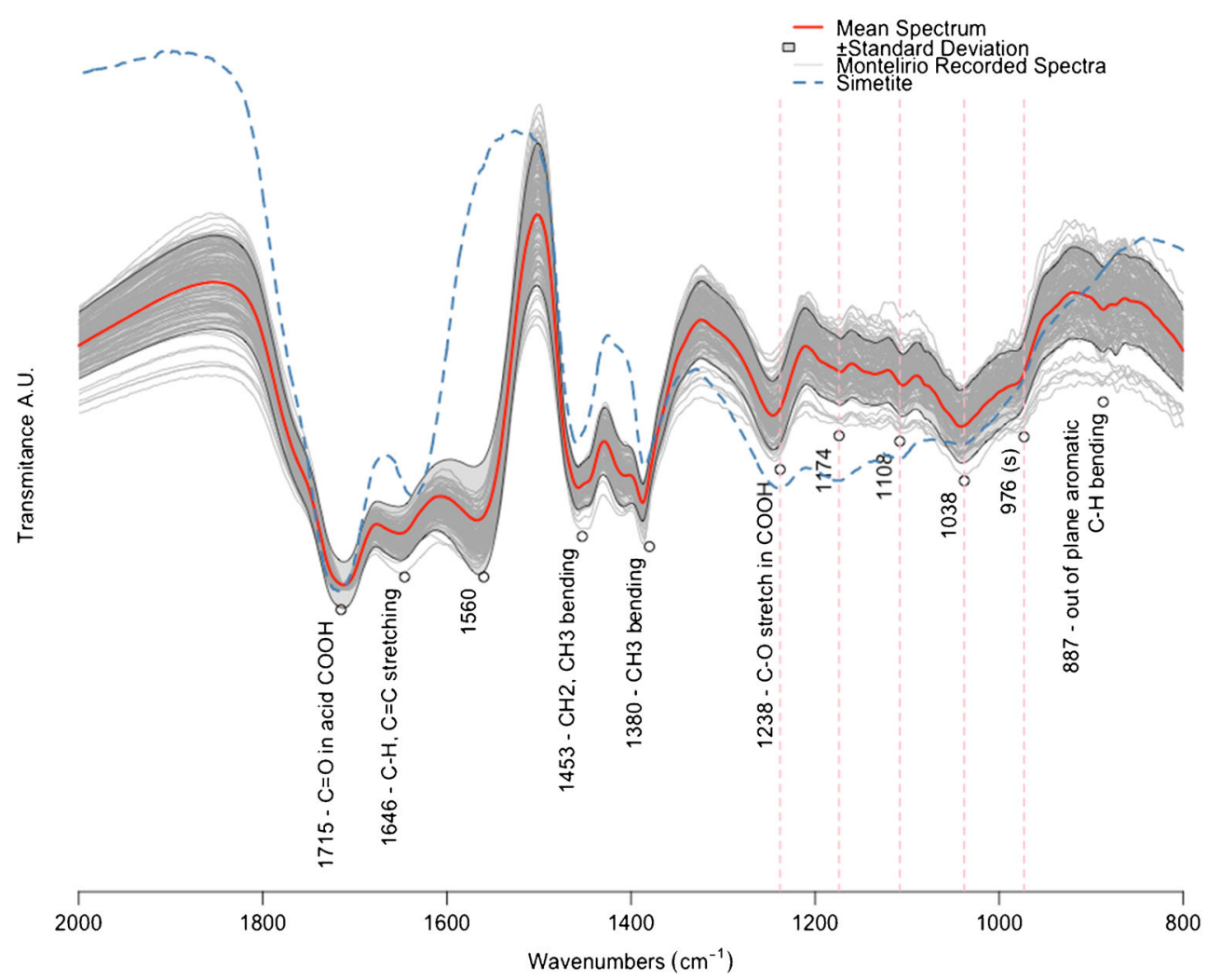

the sample by the alkaline environment, whether the sample was taken from bead's superficial crust or core. This band at $c$. $1560 \mathrm{~cm}^{-1}$ is also present in the amber bead from Cova del Gegant (see below), where $\mathrm{pH}$ is $c$. 8.4-8.3.

Taking into account that oxidation and deterioration of amber is a surface phenomenon (Shashoua et al. 2006) that is manifested as a crust that may lead to the surface flaking off, sampling of core or surface crust may be responsible for the shape and intensity of this band (Fig. 12). Determining whether the sample is taken from the crust or core is extremely difficult in the case of the Montelirio beads as for almost all of them the surface has completely flaked off, and is undistinguishable from the amber core (Fig. 14).

Bands recorded at c. 1646 and $887 \mathrm{~cm}^{-1}$, which are attributed to $\mathrm{C}=\mathrm{H}$ stretching, $\mathrm{C}-\mathrm{C}$ stretching, and $=\mathrm{CH}_{2}$ out-ofplane bending vibrations in exocyclic methylene groups, have been recorded for those spectra that fall outside the tendency marked by the mean $\pm \mathrm{sd}$ (Fig. 12). These bands are dependent on the maturity and degree of oxidation of the resin (Langenheim 1969; Shashoua et al. 2006; Pastorelli 2009: 18, Table 2.2; Havelcová et al. 2016).

Therefore, the differences observed in Fig. 12 are most likely due to sampling performance. We believe that samples that were taken from the core area of the amber, and therefore less oxidized, present less intense bands at $c .1650$ and $887 \mathrm{~cm}^{-1}$ and a more intense band at c. $1735 \mathrm{~cm}^{-1}$. The C-H bending mode vibration at $c .887 \mathrm{~cm}^{-1}$, although typically absent on referenced simetite spectra, has occasionally been reported (Beck and Hartnett 1993).

The spectroscopic comparison between the simetite consensus spectrum and the 131 recorded spectra for the Montelirio tholos beads indicates that first, the bands in the origin fingerprint region (1240-970 $\mathrm{cm}^{-1}$ ) match both the consensus spectra for simetite and the described bands of published reference simetites (Beck and Hartnett 1993; Beck 1995; Angelini and Bellintani 2005; Murillo-Barroso and Martinón-Torres 2012; van der Werf et al. 2016). Second, a feature band ${ }^{3}$ at $c$. $1560 \mathrm{~cm}^{-1}$ that is absent from simetite consensus spectrum is attributed to succinate salt, a by-product of deterioration processes caused by the alkaline burial environment. Third, the relative intensities of the recorded bands at $c$. 1715,1646 and $887 \mathrm{~cm}^{-1}$ are believed to be dependent on the degree of preservation/oxidation and the sampling area.

In addition, although the data might appear somewhat heterogeneous, this is not the case after a close examination. Only 15 out of 131 samples fall outside the tendency marked by the standard deviation for the Montelirio tholos mean spectrum. Observed differences are most likely to be due to the pellet preparation process, particularly to particle size (manual grinding) and particle dispersion ( $\mathrm{mg}$ of sample) or state of preservation.

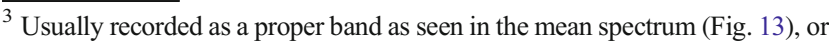
as a shoulder as seen in Fig. 12.
} 


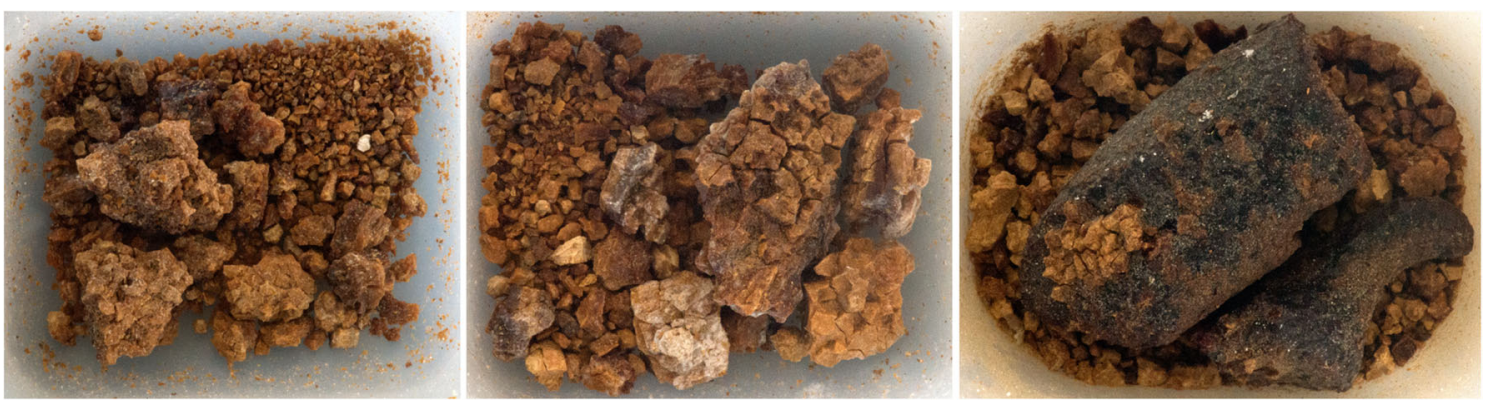

Fig. 14 Montelirio tholos beads showing oxidation and degradation phenomena. Photographs were taking without removing the beads from the museums packs

Bearing in mind the above and considering that the Montelirio tholos spectra match consensus spectra and reference patterns collected to date for simetite in the most diagnostically useful region (Beck 1971; Beck and Hartnett 1993; van der Werf et al. 2016), while the bands recorded here that are absent from the consensus spectra may be attributed to preservation issues, the most likely origin of this amber is Sicily.

\section{Anta Grande do Zambujeiro, Anta da Capela, Anta Grande da Comenda da Igreja, Alcalar Monuments 3 and 4, and Cova del Gegant}

The samples from Anta Grande do Zambujeiro, Anta da Capela, Anta Grande da Comenda da Igreja and Alcalar Monuments 3 and 4 yielded very similar spectra (Fig. 15). As regards the origin of the raw material, all spectra show a distinctive $\mathrm{COOH}$ C-O stretch vibration at $1238 \mathrm{~cm}^{-1}$ together with a set of absorption bands at $c .1174,1108,1038$ and $976 \mathrm{~cm}^{-1}$ typical of simetite. The band at $c .1560 \mathrm{~cm}^{-1}$ observed in the Montelirio assemblage appears in the Anta Grande do Zambujeiro and Anta Granda da Comenda da Igreja spectra in the form of a weak shoulder (Fig. 15), and in Cova del Gegant as an intense band. As mentioned above, we believe that the development of this band at $c .1560 \mathrm{~cm}^{-1}$ is due to the presence of succinate salt as by-product of degradation processes caused by an alkaline burial environment. Therefore, the higher the $\mathrm{pH}$ is, the more intense the band will be.

Like the Montelirio assemblage, spectra from Anta Grande do Zambujeiro, Anta da Capela, Anta Grande da Comenda da Igreja, Alcalar Monuments 3 and 4, and Cova del Gegant match consensus spectra and reference patterns collected to date for simetite in the most diagnostically useful region (Beck
Fig. 15 Anta Grande do Zambujeiro, Anta da Capela, Anta Grande da Comenda da Igreja, Alcalar Monuments 3 and 4 , and Cova del Gegant bead assemblage FTIR spectra

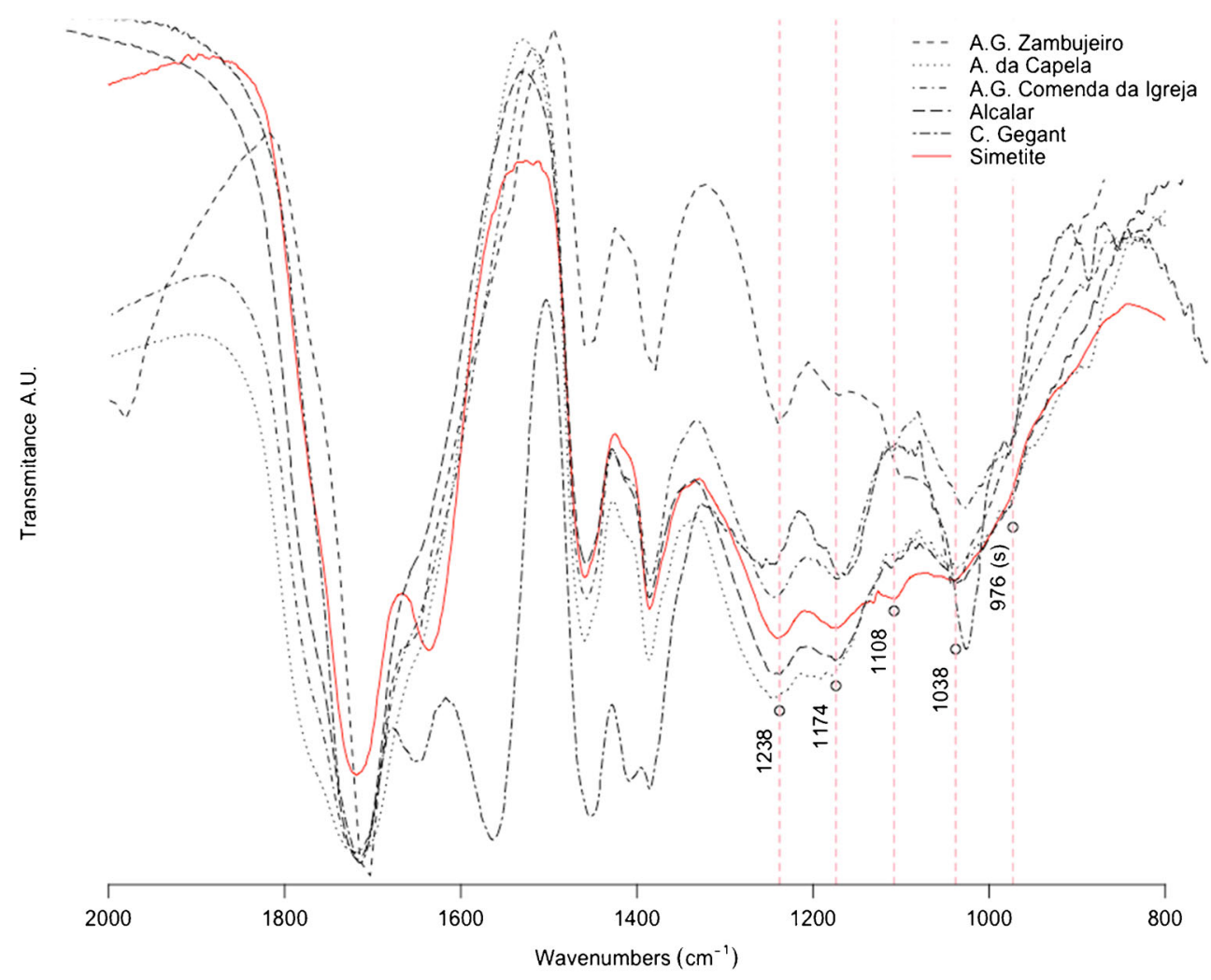


Fig. 16 Cueva de las Ventanas bead FTIR spectrum compared to the succinite reference spectrum, together with band assignments

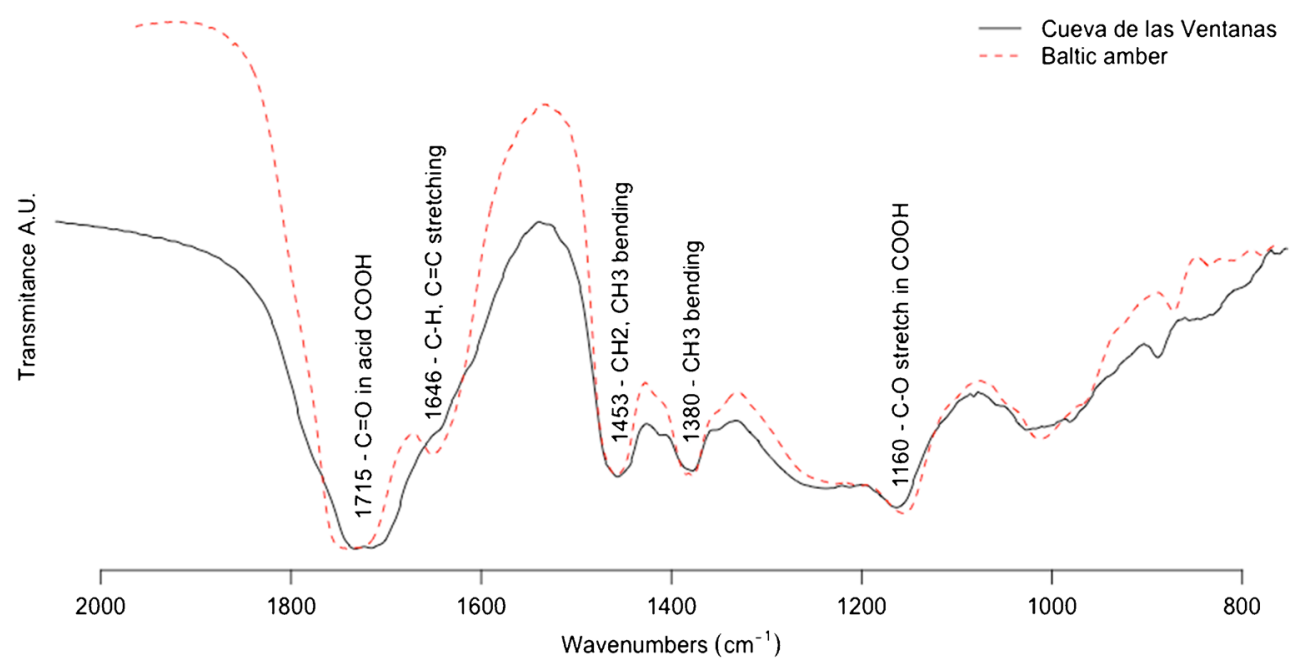

1971; Beck and Hartnett 1993; van der Werf et al. 2016). Thus, the most likely origin of this amber is Sicily.

However, of the six beads from Cova del Gegant, only two have yielded a recognizable amber spectrum, while the remaining four samples have yielded spectra where phosphate bands were clearly recognizable together with other resinite bands. This very particular case will be fully developed in a forthcoming paper.

\section{Cueva de las Ventanas}

Cueva de las Ventanas FTIR spectrum (Fig. 16) shows the typical Baltic shoulder, an intense absorption band in the
1160-1150 $\mathrm{cm}^{-1}$ region, preceded by a characteristic band between 1250 and $1180 \mathrm{~cm}^{-1}$ (Beck et al. 1965). The Baltic origin of the amber used to manufacture this bead seems therefore unquestionable.

\section{Monte da Pena/Povoado da Pena/Tholos do Barro} and Quinta do Anjo

For the Monte da Pena samples, the diamond crystal ATR modular complement of the spectrometer was used directly over the bead. Recorded spectra from Monte da Pena are very different from the other analyzed beads (Fig. 17). First: There is no signal between 2000 and $1200 \mathrm{~cm}^{-1}$. Second: In the
Fig. 17 Monte da Pena/Povoado da Pena/Tholos do Barro beads FTIR spectra compared to quartz and Paraloid B72 reference spectra

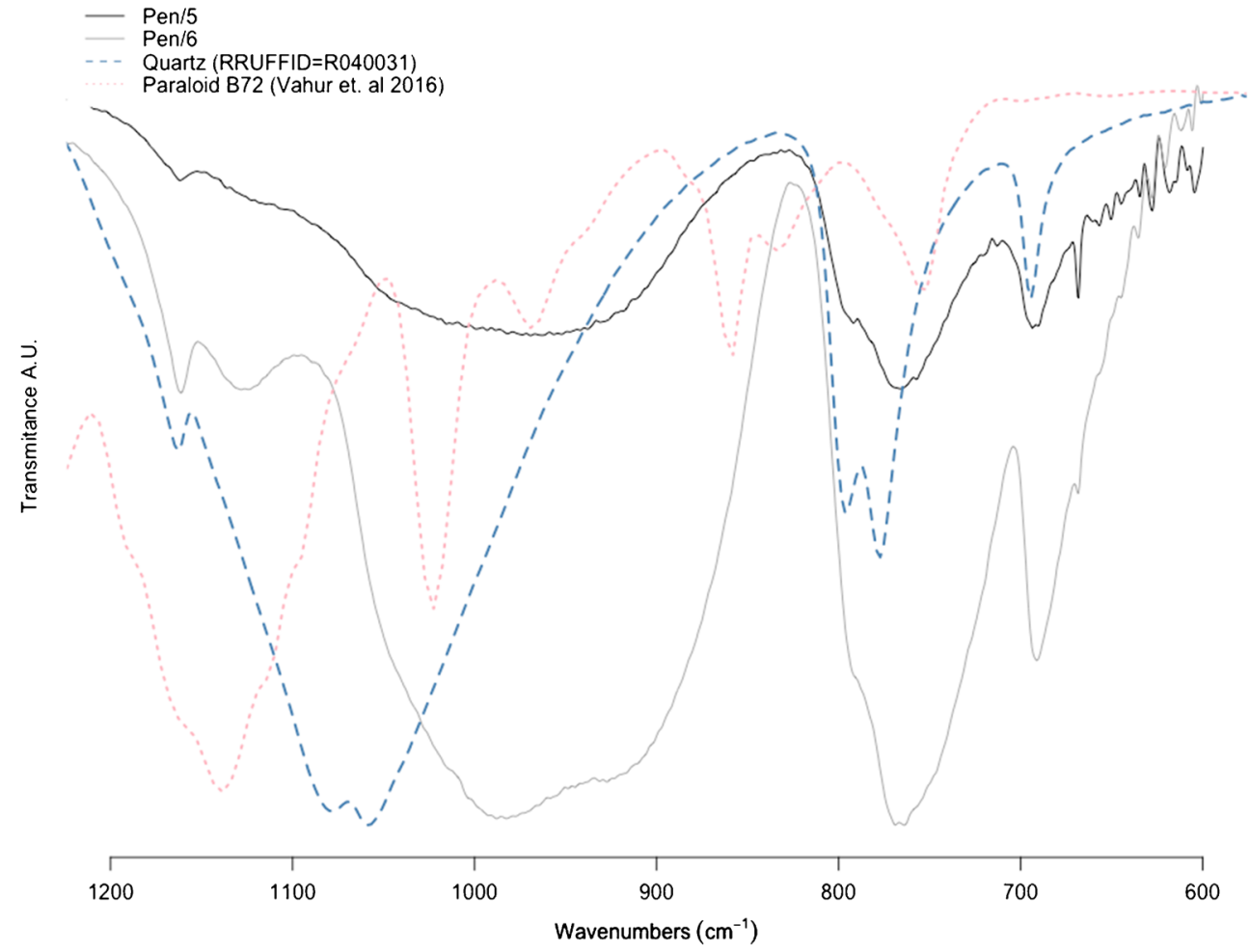


Fig. 18 Monte da Pena/Povoado da Pena/Tholos do Barro beads Raman spectra compared to quartz

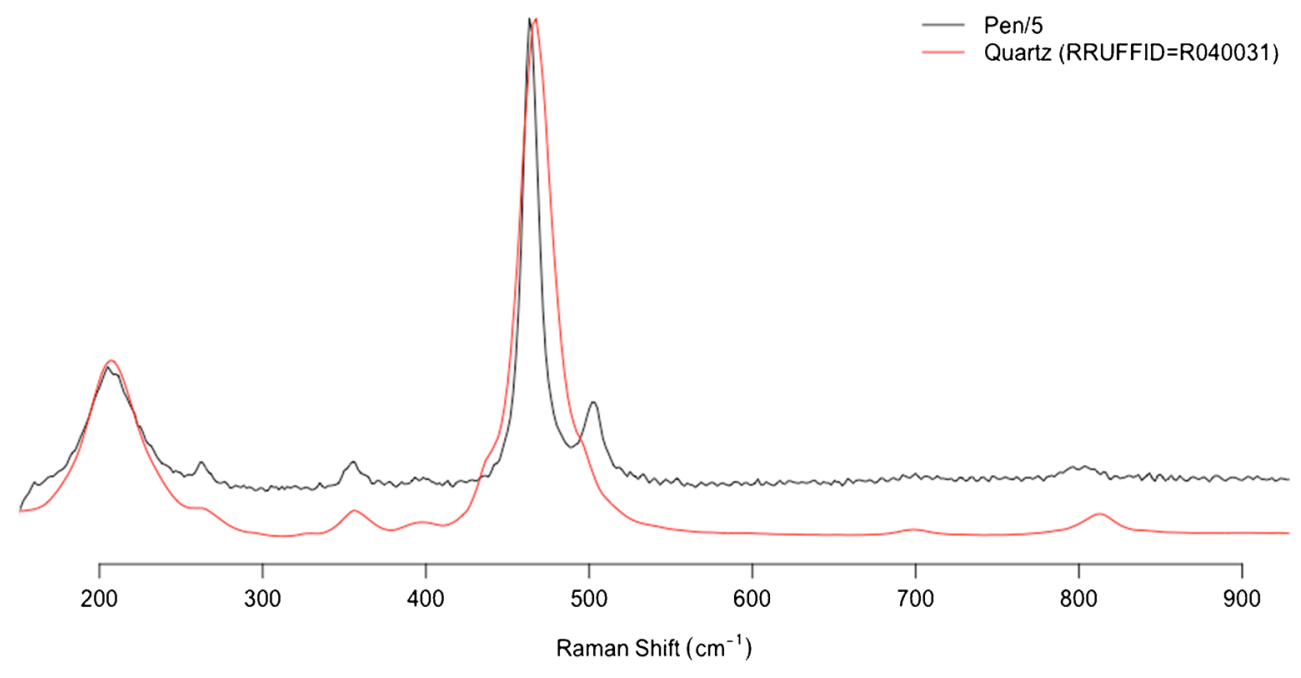

diagnostic region, no recognizable amber pattern is seen. Instead, a set of bands at $c .1162,1130$ and $795 \mathrm{~cm}^{-1}$ are assigned to $\mathrm{Si}-\mathrm{O}$ stretching modes, and a band at $\mathrm{c}$. $690 \mathrm{~cm}^{-1}$ is assigned to $\mathrm{Si}-\mathrm{O}-\mathrm{Si} / \mathrm{O}-\mathrm{Si}-\mathrm{O}$ bending mode. These sets of bands are compatible with quartz. The yellow coloration of the bead may come from the presence of evenly distributed structural iron oxide and/or hydrous oxide.

The remaining unassigned bands in the FTIR spectra could, therefore, be related to (1) the structural $\mathrm{Fe}$, or (2) to the use of Paraloid or another conservation agent applied to the beads (Fig. 17).

In addition to FTIR measurements, we have performed dispersive confocal $\mu$-Raman spectrometry. ${ }^{4}$ The recorded spectrum fully matches that of quartz as shown in Fig. 18. Therefore, both samples from Monte da Pena must be classified as macro crystalline ferruginous quartz instead of amber.

The Quinta do Anjo bead is indeed another quartz artefact according to its chemical composition ${ }^{5}$ (Table 3 ). It is transparent and clear with a slightly smoky yellow hue.

\section{Los Millares}

The two beads recorded as amber in the Museo de Almería's database yielded the typical mica SWIR spectrum ${ }^{6}$ and

\footnotetext{
${ }^{4}$ Data was acquired using a HORIBA Jobin Yvon LabRAM HR system. The laser diode, when operated at a wavelength of $532.06 \mathrm{~nm}$, produces up to $15 \mathrm{~mW}$ of power in the source. Filters to reduce the laser's power were not used. The acquisition time was $32 \mathrm{~s}$ per acquisition, up to a maximum of 20 . The spectral measurement range chosen was between 100 and $1800 \mathrm{~cm}^{-1}$ using a $100 \times$ lens with a CCD multi-channel detector. The selected measurement is accurate to $1 \mathrm{~cm}^{-1}$. The measurement area selected was $1000 \mu \mathrm{m}$ in diameter.

${ }^{5}$ Measured with an Oxford Instrument XMET-7500 EDX elemental analyser. Chemical composition was dominated by $\mathrm{Si}, \mathrm{Al}$ and $\mathrm{K}$, together with other minor elements as $\mathrm{Fe}, \mathrm{Rb}$..

${ }^{6}$ Measured with a Panalytical ASD Terraspec HALO spectrometer. The device identified the beads against its own database as muscovite and brammalite.
}

chemical composition (Fig. 19, Table 3). Therefore, these beads have been characterized as yellow micas very similar in appearance and chemical composition to those found in the Bronze Age cist at Pessegueiro (Sinnes, Portugal) (Odriozola et al. 2016a).

The misclassification of yellowish micas and quartz as amber is not uncommon. It is, indeed, a commonly made mistake when dealing with personal adornments. Both materials, micas and quartz, in their macro crystalline varieties were frequently used in funerary contexts during Late Prehistory.

\section{AMS-radiocarbon dating}

The AMS-radiocarbon date obtained for the sample of human humerus, MNA 2003.74.96 (Table 4), shows a calibrated date that roughly spans the second half of the 4 th millennium BCE. This date is very consistent in terms of the material culture finds (see above), which locate this monument in the transition from the 4th to 3rd millennium BCE.

Figures 20 and 21 show the calibrated dates for Table 4 and a non-parametric phase model used here to estimate activity phases through a full Bayesian Gaussian mixture model ${ }^{7}$ of the radiocarbon dates (Parnell et al. 2011). Four phases can be clearly observed: a first phase, represented by Alberite and Campo de Hockey and spanning from 4246 to 3915 BCE, a second phase, represented by Anta Capela and Cueva de los Cuarenta and spanning from 3765 to $3221 \mathrm{BCE}$ (approximately the third quarter of the 4th millennium BCE), a third phase, represented by Valencina de la Concepción, Anta Grande do Zambujeiro, Valle de las Higueras and Errekatxuetako Atx, from 2891 to 1986 BCE (third millennium BCE), and a fourth phase, represented by Cueva de las Ventanas and Cova del Gegant, from to 1894 to 1340 BCE (second quarter of second millennium BCE).

\footnotetext{
${ }^{7}$ https://cran.r-project.org/web/packages/Bchron/index.html
} 
Table 3 Chemical composition of analyzed quartz beads expressed as atomic percentage

\begin{tabular}{lrlllllllllllll}
\hline & $\mathrm{Al}$ & $\mathrm{Si}$ & $\mathrm{P}$ & $\mathrm{S}$ & $\mathrm{Cl}$ & $\mathrm{K}$ & $\mathrm{Ca}$ & $\mathrm{Ti}$ & $\mathrm{Cr}$ & $\mathrm{Fe}$ & $\mathrm{Rb}$ & $\mathrm{Sr}$ & $\mathrm{Sn}$ \\
\hline Quinta do Anjo & 4.75 & 89.50 & 2.59 & 1.05 & - & - & 1.96 & - & 0.03 & 0.12 & - & - \\
CE00845 & 41.02 & 39.48 & - & 0.66 & 3.88 & 13.11 & 0.33 & 0.08 & 0.04 & 0.78 & 0.58 & 0.01 & 0.05 \\
CE00846 & 41.57 & 40.85 & - & 0.60 & 2.78 & 12.83 & 0.37 & 0.07 & - & 0.65 & 0.25 & - & 0.02 \\
\hline
\end{tabular}

\section{Iberian ambers from the 6th to 2nd millennia BCE}

While any overarching perspective must remain preliminary, it is worth highlighting some apparent trends that may serve as pointers for future research. In this section, we attempt to integrate our new data for the Iberian Peninsula with the reviewed information from Murillo-Barroso and MartinónTorres (2012: 201-205 Table 1).

In the Iberian Peninsula, consumption patterns may follow a first pioneering stage, when first non-formal contacts are established with the procurement area or chain of nodes that connect the source area with the Iberian Peninsula; a second stage, when contacts increase in number and start to become regular; a third stage when contacts probably formed an institutionalized relationship (sensu Renfrew 2001), and a fourth stage when the whole community would have gained access to this material due to the strong links developed under the institutionalization of trade. This phase opens a pathway to the decline in its use as it no longer satisfies the social need of differentiation in increasingly complex societies.

Even though an amber trade route ${ }^{8}$ cannot be established for the Iberian Paleolithic - all analyzed samples are identified as local Cretaceous ambers (Álvarez Fernández et al. 2005), a Mediterranean route may be proposed for the Neolithic Iberian ambers because all the finds, except for the three beads from Campo de Hockey, ${ }^{9}$ originated in Sicily (Table 1). At the 5th-4th millennia BCE transition, when the amber trade is first documented in the Iberian Peninsula, the first alpine jade axe reaches the Iberian Peninsula (Cassen et al. 2012; Fábregas Valcarce et al. 2012) and the first exploitation of variscite deposits in the Iberian Peninsula starts (Odriozola et al. 2016b). Although Orca de Seixas ${ }^{10}$ dates (AlmagroGorbea 1972) should be taken with extreme caution. Both, Orca de Seixas Chousa Nova dates (Dominguez Bella and Bóveda 2011) are in good agreement with the dates obtained for the amber beads' contexts; $c$. last quarter of 5 th and first

\footnotetext{
${ }^{8}$ For a detailed discussion of whether trade routes existed or not, the reader is recommended to consult (Renfrew 1993; Hughes-Brock 2011).

${ }^{9}$ Campo de Hockey necropolis beads spectra remain unpublished and a Sicilian origin has not been rejected. They are said to be non-Baltic ambers (Vijande Vila et al. 2015).

${ }^{10}$ Radiocarbon dates from Orca de Seixas are subject to debate because the recovered finds consist mainly of bell beakers (Boaventura 2009). They are not associated to the amber beads, and therefore, must be taken with extreme caution. .
}

quarter of 4th millennia BCE. We can therefore establish a chronological range for this first pioneering stage covering the last quarter of the 5th-first quarter of the 4th millennia BCE (Fig. 20, phase 1).

The start of the Copper Age (last quarter of the 4th millennium-beginning of the 3rd millennium BCE) is a turning point in terms of the economy and demography. It is the time when the first stable settlements are founded, e.g. Perdigões, Porto Torrão, La Pijotilla, Valencina de la Concepción, Camino de las Yeseras... (Hurtado 1999; Blasco et al. 2007; Valera 2012, 2013; Valera et al. 2014), agricultural and livestock intensification occurs (Delibes de Castro 2011), and copper metallurgy spreads (Rovira Llorens et al. 2003). It is also the time when wealth, and therefore social inequalities, are recorded in burials, e.g. Millares' necropolis (Almagro and Arribas 1963), Fuente-Olmedo (Martin Valls and Delibes de Castro 1989), Valle de las Higueras (Bueno Ramírez et al. 2005), Valencina de la Concepción (García Sanjuán and Murillo-Barroso 2013), etc. All this affected the role and social use of personal adornments made from exotica. Just before the beginning of the $3 \mathrm{rd}$ millennium BCE, the number of ivory and variscite objects records exponential growth (Schuhmacher 2012; Odriozola et al. 2016b) that is paralleled by the number of amber finds, which grows spectacularly during 3rd millennium BCE (see Table 1).

During the first half of the 3rd millennium BCE, the amber route that had connected Sicily with the Iberian Peninsula since the 5th millennium BCE must have intensified its activity, as the number of finds increases dramatically from the former phase to this stage. The intensification of the activity associated with this Mediterranean amber route is also supported by the presence of an outstanding amount of Asian ivory associated with amber contexts in the PP4 Montelirio structure 10.042 10.049 (García Sanjuán et al. 2013) and in the IES ivory workshop at Valencina (Nocete et al. 2013). However, the Mediterranean route cannot have been the only route by which 'elites' were procuring exotic goods by this time. In the first half of the 3rd millennium BCE in Portugal, most of the ivory finds correspond to African elephants (Schuhmacher et al. 2009; Nocete et al. 2013), which could mean that a diversified exotica supply system was functioning in Iberia, even though all the analyzed amber has been characterized as Sicilian amber For example, Anta Capela has yielded African elephant ivory beads (Schuhmacher et al. 2009). 
Fig. 19 Los Millares beads' SWIR spectra

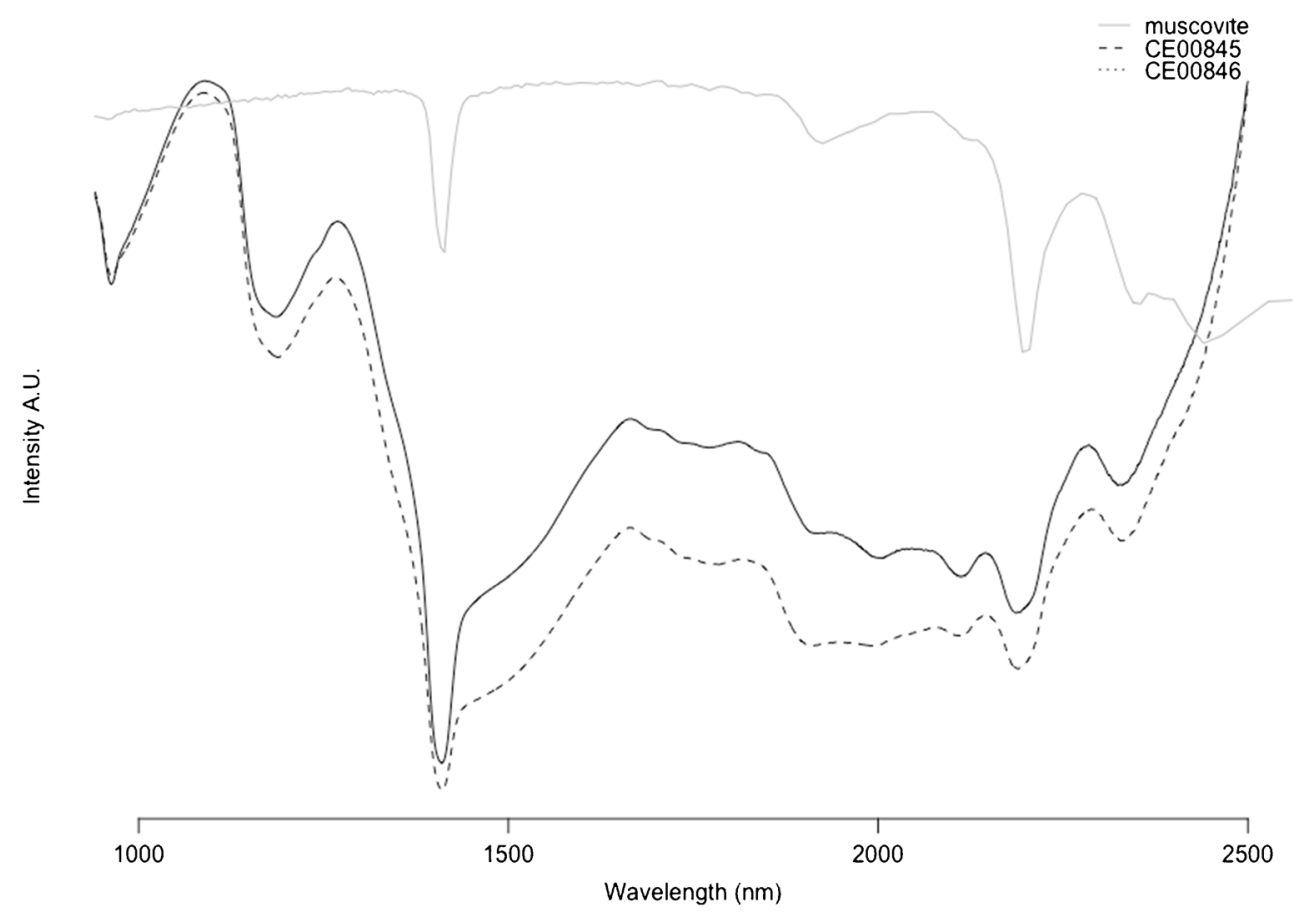

Murillo-Barroso (2016: 330) suggests, at this point, that amber trade during this period of time was carried out through indirect trade with Sardinia and Tunisia, based on the obsidian trade (Tykot et al. 2013), ostrich eggshell, and especially on African ivory recorded at Valencina de la Concepción (Schuhmacher et al. 2009; Nocete et al. 2013). However, the only obsidian items from the Central Mediterranean (Monte Arci source) are dated in the 5th to 4th millennium BCE in northeastern Iberia (five blade blanks, plus a core: (Terradas et al. 2014), and no amber items are documented in Sardinia until the second half of the 2nd millennium BCE (Bellintani 2010; Angelini and Bellintani 2016). Nevertheless, we do agree that amber exchange networks must have reached the southern Iberian coast through North Africa, whereas northeastern Iberia participated in exchange networks that connected Southern France -from the Alps- with coastal Catalonia

Table 4 Radiocarbon dates from individuals and/or contexts directly associated with amber finds in the Iberian south-west

\begin{tabular}{|c|c|c|c|c|c|c|c|}
\hline Site & Individual & Layer & Lab. code & $\mathrm{BP}$ & $\mathrm{SD}$ & Material & Bibliografía \\
\hline $10.042-10.049$ & & Main chamber. & CNA-1291 & 4161 & 34 & bone & (García Sanjuán 2013) \\
\hline Anta da Capela & 2003.74 .76 & & CNA-3543 & 4532 & 30 & humerus & \\
\hline C. de los 40 & & Assemblage 1 & CNA_2421 & 4575 & 35 & bone & (Vera Rodríguez 2014) \\
\hline Alberite* & & Ochre level & Beta- 80,602 & 5320 & 70 & charcoal & (Sttip and Tamers 1996) \\
\hline Alberite* & & Ochre level & Beta- 80,600 & 5110 & 140 & charcoal & (Sttip and Tamers 1996) \\
\hline Alberite* & & Ochre level & Beta- 80,598 & 5020 & 70 & charcoal & (Sttip and Tamers 1996) \\
\hline C. de Hockey & & E11 C14 & CNA-664 & 5650 & 40 & shell & (Vijande Vila et al. 2015) \\
\hline Valle de las Higueras 1 & & & Beta-14,275 & 3890 & 40 & bone & (Bueno Ramírez et al. 2005) \\
\hline Valle de las Higueras 3 & & & Beta-157,729 & 3830 & 40 & bone & (Bueno Ramírez et al. 2005) \\
\hline Errekatxuetako Atxa* & & Chamber (Almek) Smt8 & Beta-259,129 & 3750 & 40 & bone & (López Quintana 2015) \\
\hline Anta G. do Zambujeiro* & & & Beta-243,693 & 3910 & 40 & charcoal & (Soares and SIlva 2010) \\
\hline Cueva de las Ventanas & Young adult & & UGRA-541 & 3380 & 90 & bone & \\
\hline Cova del Gegant & Young adult (Ind \#5,67) & XXV & OxA-29,612 & 3225 & 27 & Teeth & (Daura et al. 2017) \\
\hline Cova del Gegant & Adult (Ind. \#17) & XXV & Beta-312,860 & 3270 & 30 & Teeth & (Daura et al. 2017) \\
\hline Cova del Gegant & Adult (Ind. \# 18,19) & $\mathrm{Ib} 2 \mathrm{~d} / \mathrm{Ia}$ & Beta-312,861 & 3200 & 30 & Teeth & (Daura et al. 2017) \\
\hline
\end{tabular}

*These dates do not belong to individuals, they rather belong to clear depositional contexts where beads were found, with exception to Anta Grande do Zambujeiro which has been discussed above 
Fig. 20 Calibrated dates for Table 4 and a non-parametric phase model of the radiocarbon dates

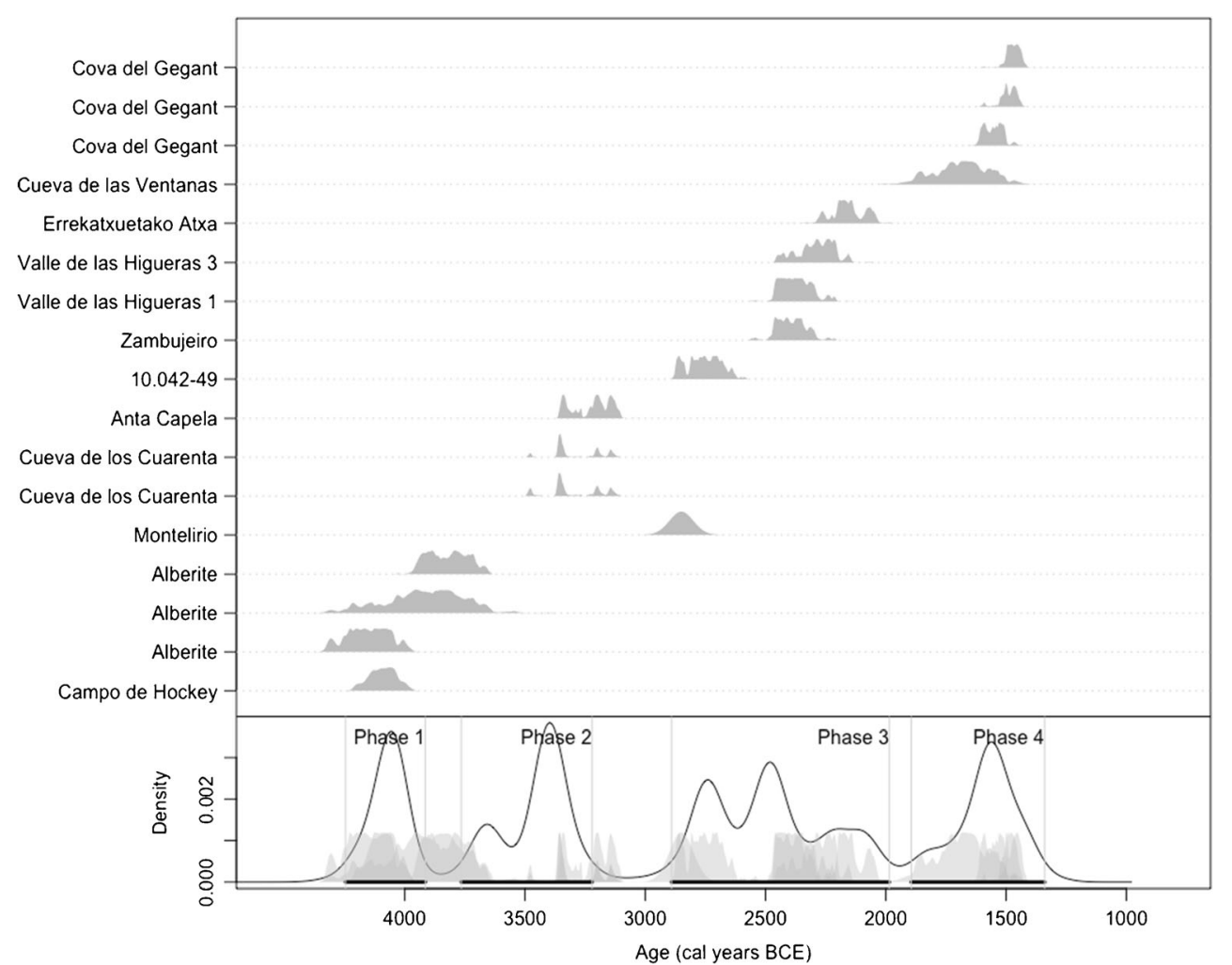

from the 5th millennium BCE, e.g. Alpine jade axe imports (Vaquer et al. 2012), and obsidian (Terradas et al. 2014).

A large number of amber finds are dated in the second half of the 3rd millennium BCE, with Anta Grande do Zambujeiro as the greatest exponent with $>168$ Sicilian amber finds. The greatest difference with the first half of the 3rd millennium BCE is diversification in amber supply sources. Baltic amber is traded for the first time (Larrarte) and local Cretaceous amber is exploited again (Trikualtzi I and Cova de La Pastora). However, the use of Baltic and local Cretaceous amber is constrained to the northern and eastern Iberian Peninsula, while the south of the Iberian Peninsula is still supplied by the Mediterranean amber route that had been operating since the 5th millennium BCE.

By this time, Baltic amber finds record a noteworthy increase and reach their maximum expansion (associated with bell beakers) towards western Europe -Czech Republic, Western France, Great Britain, Holland and Austria (du Gardin 2002), including northeastern Iberia. This most likely implies that previous exchange networks in use since the 5th millennium BCE (Alpine jade axes) were still active, bringing Baltic amber to this region of Iberia, while at the same time Sicilian amber was reaching the southern Iberian Coast. This 'French connection', also supported by the arrival of Northern European pottery styles ('pastillas repujadas') and CZM Bell Beakers (Hurtado and Amores 1982, 1985), indicates links with northern Europe via the South of France (MurilloBarroso and Martinón-Torres 2012: 209).
The diversification of supply sources is not exclusive to amber but has also been recorded for ivory. During the second half of the 3rd millennium BCE, Asian, African and fossil ivory was being traded and worked together, e.g. in Valencina de la Concepción (Nocete et al. 2013: 15891590). However, while radiocarbon dates show a clearly defined period for ivory, the debate to which the Trikualtzi I, Larrarte $^{11}$ and Cova de La Pastora ${ }^{12}$ dates are subject obscures the beginning of this phenomenon for amber. Trikualtzi I and Larrarte megaliths yielded non-Sicilian ambers together with gold foil-beads and bell beakers vessels, pointing to a chronology compatible with that of this last phase. La Pastora Cave attested local Cretaceous amber use in a chronology spanning from the 5th to 2nd millennia BCE (McClure et al. 2010; García-Puchol et al. 2013).

The diversification of supply systems have also been recorded in Italy, where simetite was solely consumed from the

\footnotetext{
${ }^{11}$ Radiocarbon calibrated dates for charcoal from the base levels of these megaliths range from the last quarter of the 4th to first quarter of the $3 \mathrm{rd}$ millennia BCE. However, the laboratory responsible for the radiocarbon dating reported that due to small sample size they were not able to perform standard procedures for sample preparation and that dates must be taken with precaution. In addition, scholars agreed that this date is overestimated if compared with the material assemblage recovered (Mujika and Armendariz 1991; Ontañón 2003).

12 The cave was in use from the 3 rd quarter of the 4th millennium to the Bronze Age. However, recent research has shown a major use during the second half of the 4th millennium and a Bell Beaker phase (McClure et al. 2010; García Puchol et al. 2013). No chronological attribution is available for the amber beads.
} 
Fig. 21 Distribution of the Iberian amber finds by relevant chronological periods and indication of amber provenance

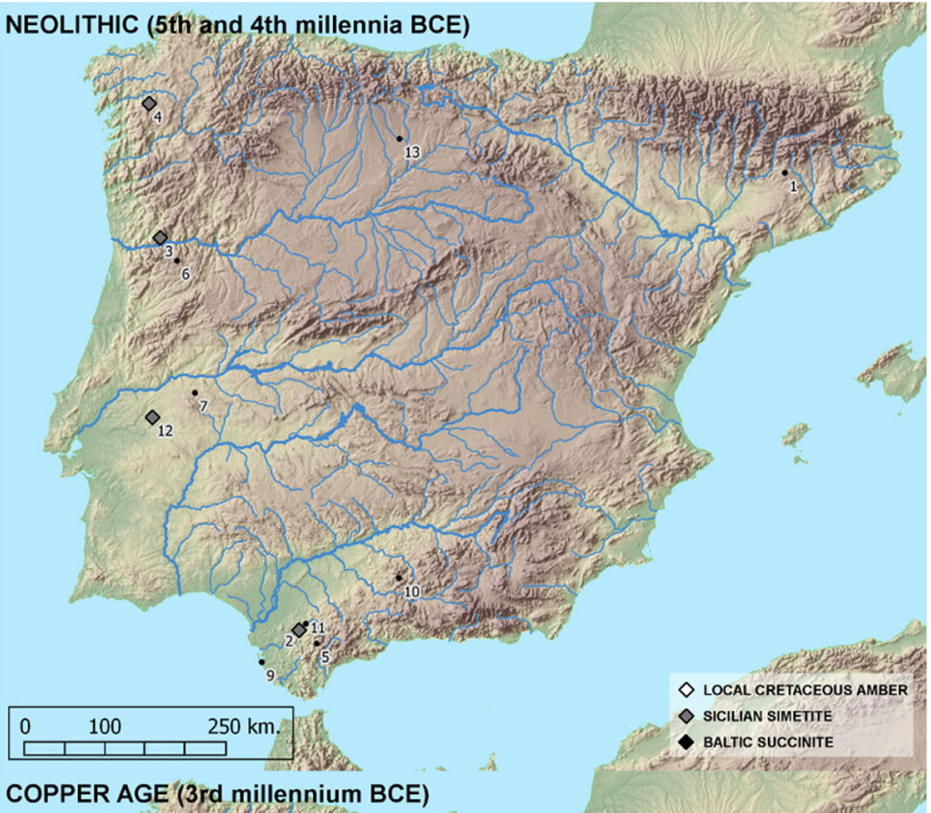

COPPER AGE (3rd millennium BCE)

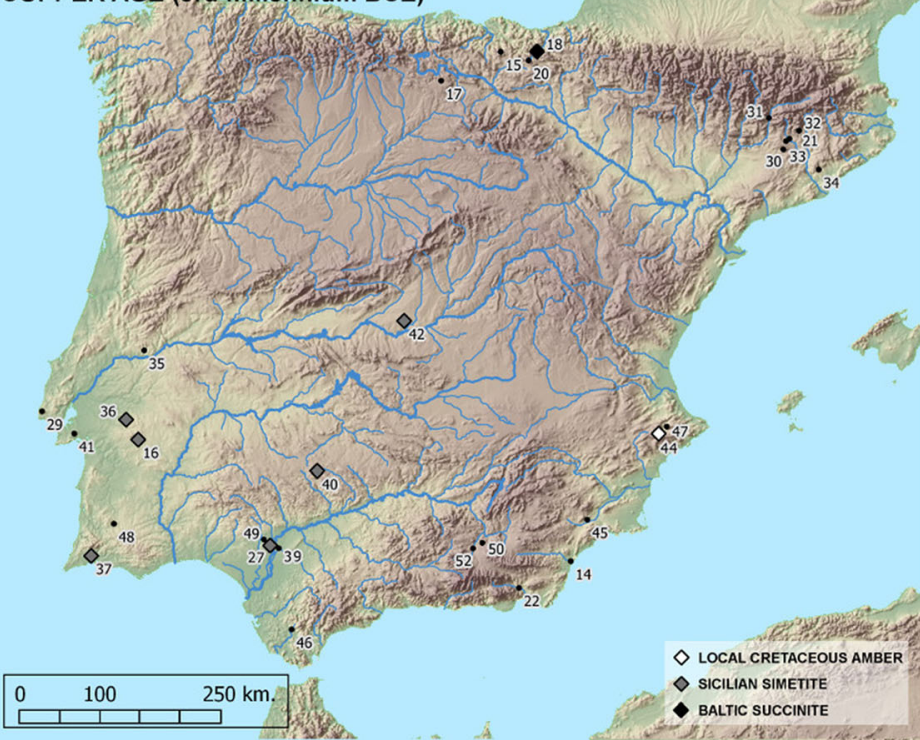

BRONZE AGE (2nd millennium BCE)

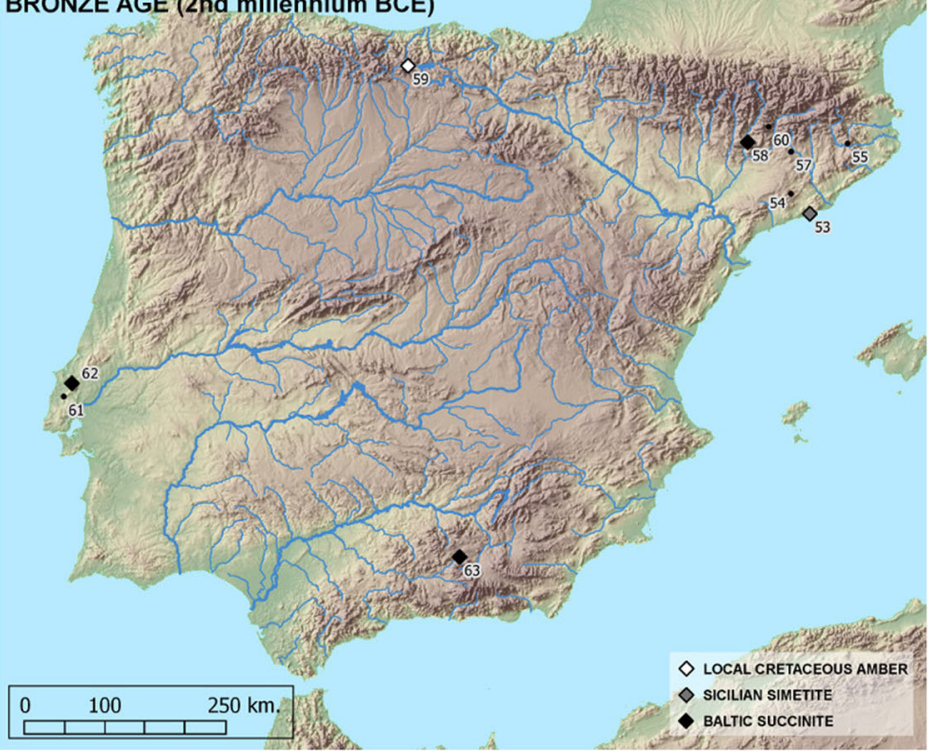


4th millennium BCE to $1800-1600$ cal BCE, when the pattern started to change and the first Baltic ambers are recorded in Northern and Central Italy and Sicily together with a large increase in the number of finds (Bellintani 2010; Angelini and Bellintani 2016). From this moment onwards all the Italian archaeological ambers were worked exclusively out of Baltic amber ${ }^{13}$ (Angelini and Bellintani 2016). However, by this time Greece had become the focal point of trade and ambers with different spectral signatures to that of succinite or simetite have been recorded, pointing to a very diversified and well established exotica supply system (Angelini and Bellintani 2016).

Nonetheless, during this procurement shift, the last simetites spread across the Mediterranean Sea, reaching Greece (Vayenas tholos, Pylos, Greece) c. 2200-1600 cal BCE (Middle to Late Heladic I-III) (Beck and Hartnett 1993; Angelini and Bellintani 2016) and the northeastern Iberian Peninsula (Cova del Gegant) c. 1600-1400 cal BCE. At the same time as the Baltic Sea became the main amber supplier in the Mediterranean (1800-1400 cal BCE), the use of personal adornments made from Baltic amber established a new trading vector towards Central Europe (South of Germany), Southeast France (the Alps) and Greece, and almost disappeared from the Baltic Sea region, Western France and Great Britain (du Gardin 2002: 223).

The increasing demand for amber as a raw material for beads and personal ornaments seems to be a reflection and active practice in the processes of development of social complexity during the late 4 th and 3rd millennia BCE in the Iberia Peninsula. This demand is indicative of the importance that long-distance trade assumed in the development of social relations at the time, when non-local 'out of the ordinary' materials were called to play diverse roles related to social status. They materialized social differences by means of their asymmetric display among the living and the dead.

Later, when access to 'out of the ordinary' raw materials like amber became not so uncommon, social differentiation would likely rely on the number and size of such items and their combination with other prestigious items, such as ivory, variscite, gold, bell beakers... This is the case for most late 3rd millennium BCE burials, but particularly for Valencina de la Concepción burials and Anta Grande do Zambujeiro, which accumulate $83 \%$ of the finds and almost $95 \%$ in weight of the amber in the Iberian Peninsula (see Tables 1 and 2).

Acknowledgements The authors wish to thank the Museu de Évora (Antonio Alegria), Museo Nacional de Arqueología (Antonio Carvalho), Museo Arqueológico de Sevilla (Ana Navarro and Concha Sanmartín), Museo de Almería (María Isabel Pérez and Manuel

\footnotetext{
13 The Trinitapoli (1700-1400 cal BCE) amber origin remains unknown (Angelini and Bellintani 2005, 2016; Bellintani 2010), although it may have had a Sicilian origin. If this is true, these could be considered the latest-used Italian simetite beads.
}

Ramos), and Museo de Granada (Isidro Toro) for access to the collections there deposited.

Funding The authors acknowledge the Ministerio de Economía y Competitividad (MINECO) for the financial support (HAR2012-34620) and the Ministerio de Ciencia e Innovación (MICIN) for the postdoctoral grants under the program Juan de la Cierva (C.P. Odriozola JCL-201110491 and M. Sanz FJCI-2014-21386), the University of Sevilla for a postdoctoral contract (C.P. Odriozola) and a predoctoral grant (J.A. Garrido-Cordero) under the V Plan Propio de Investigación. J. Daura holds a postdoctoral grant (SFRH/BPD/100507/2014) from the Portuguese Fundação para a Ciência e a Tecnologia using funding from the FSE/POPH.

\section{References}

Afonso Marrero JA, Cámara Serrano JA, Martínez Fernández G, Molina González F (2011) Objects in exotic raw materials and the hierarchical structure of the tombs in the Los Millares necropolis (Santa Fe De Mondújar, Almería, Spain). In: García Sanjuán L, Scarre C, Weatley DW (eds) Exploring time and matter in prehistoric monuments: absolute chronology and rare rocks in European megaliths: proceedings of the 2nd European megalithic studies group meeting, (Seville, Spain, november 2008) $=$ Explorando el tiempo y la materia en los monumentos prehistóricos: cronología absoluta y rocas raras en los megalitos europeos: actas de la Segunda Reunión del Grupo Europeo de Estudios Megalíticos (Sevilla, España, noviembre 2008). Junta de Andalucía, Consejería de Cultura, Antequera (Málaga)

Alday Ruiz A (1987) Los elementos de adorno personal y artes menores en los monumentos megalíticos del País Vasco merindional. Estud Arqueol Alavesa 15:103-154

Almagro (1962) El ajuar del Dolmen de La Pastora de Valentina del Alcor (Sevilla). Sus paralelos y su cronología Trabajos de Prehistoria 5:538

Almagro M, Arribas A (1963) El poblado y la necrópolis megalítica de Los Millares (Santa Fe de Mondújar, Almería). Consejo Superior de Investigaciones Científicas, Barcelona

Almagro-Gorbea M (1972) C-14, 1972. Nuevas fechas para la Prehistoria y la Arqueología peninsular. Trab Prehist 29:228

Álvarez Fernández E, Peñalver Mollá E, Delclòs Martínez X (2005) La presencia de ámbar en los yacimientos prehistóricos (del Paleolítico Superior a la Edad del Bronce) de la Cornisa Cantábrica y sus fuentes de aprovisionamiento. Revista de prehistoria y arqueología, Zephyrus, pp 159-182

Angelini I, Bellintani P (2005) Archaeological ambers from northern ITALY: an FTIR-drift study of provenance by comparison with the geological Amber database*. Archaeometry 47:441-454. https://doi.org/10.1111/j.1475-4754.2005.00212.x

Angelini I, Bellintani P (2016) The use of different amber sources in Italy during the bronze age: new archaeometric data. Archaeol Anthropol Sci:1-12. https://doi.org/10.1007/s12520-016-0452-7

Arribas A (1953) El ajuar de las cuevas sepulcrales de los Blanquizares de Lébor (Murcia). Memorias de los Museos Arqueológicos Provinciales:78-126

Arribas Palau A, Molina González F, Sáez Pérez L et al (1979) Excavaciones en Los Millares (Santa Fe de Mondújar, Almería). Campaña de 1978 y 1979. Cuadernos de Prehistoria y Arqueología de la Universidad de Granada 4:61-109

Arribas Palau A, Molina González F, Sáez Pérez L et al (1981) Excavaciones en Los Millares (Santa Fe de Mondújar, Almería). Campaña de 1981. Cuadernos de Prehistoria y Arqueología de la Universidad de Granada 6:91-121 
Arribas Palau A, Molina González F, Sáez Pérez L et al (1983) Excavaciones en Los Millares (Santa Fe de Mondújar, Almería). Campañas de 1982 y 1983. Cuadernos de Prehistoria y Arqueología de la Universidad de Granada 8:123-47

Bayliss A, Beavan N, Ramsey CB, et al (2016) CAPÍTULO 21. LA CRONOLOGÍA RADIOCARBÓNICA DEL THOLOS DE MONTELIRIO. In: Fernández Flores Á, García Sanjuán L, DíazZorita Bonilla M (eds) MONTELIRIO. Un gran monumento megalítico de la Edad del Cobre. JUNTA DE ANDALUCÍA. Consejería de Cultura, pp 485-502

Beck CW (1965) The origin of the amber found at Gough's Cave, Cheddar, Somerset. Proceedings of the University of Bristol Spelaeology Society 10:271-276

Beck CW (1982) Authentication and conservation of amber: conflict of interests. Stud Conserv 27:104-107. https://doi.org/10.1179/sic. 1982.27. Supplement-1.104

Beck CW (1971) Amber from the eneolithic cemetery of Laterza. Origini 5:301-305

Beck CW (1995) The provienence analysis of amber. Am J Archaeol 99: $125-127$

Beck CW, Hartnett HE (1993) Sicilian amber. In: Beck CW, Bouzek J (eds) Proc. 2nd Int. Conf. Amber in Archaeology. Liblice. 1990. Czech Academy of Sciences, Prague, pp 36-47

Beck CW, Wilbur E, Meret S (1964) Infra-red spectra and the origin of amber. Nature 201:256-257. https://doi.org/10.1038/201256a0

Beck CW, Wilbur E, Meret S et al (1965) The infrared spectra of amber and the identification of Baltic amber. Archaeometry 8:96-109

Belchior da Cruz P (1906) As Grutas de Palmella. Boletim da Sociedade Archaeologica Santos Rocha 1:87-98

Bellintani P (2010) Ambra. Una materia prima dal nord (ma non solo). Ambra per Agamennone Indigeni e Micenei tra Egeo, Ionio e Adriatico nel II millennio aC Catalogo della mostra (Bari, 28 maggio-16 ottobre 2010) Palazzo Simi e Museo Civico Storico. Bari 2010:139-144

Berdichewsky Scher B (1964) Los enterramientos en cuevas artificiales del Bronce I Hispánico. Consejo Superior de Investigaciones Científicas. Universidad de Madrid, Madrid

Binford LR (1962) Archaeology as anthropology. Am Antiq 28:217-225

Blasco C, Delibes G, Baena J et al (2007) El poblado calcolítico de Camino de las Yeseras (San Fernando de Henares, Madrid): un escenario favorable para el estudio de la incidencia campaniforme en el interior peninsular. Trab Prehist 64:151-163

Boaventura R (2009) As antas eo Megalitismo da região de Lisboa. Ph.D. Thesis, Universidade de Lisboa. Facultade de Letras. Departamento de História

Borja Barrera F, Borja Barrera C, Recio Espejo JM (2010) Estudio Geoarqueológico del Dolmen de Montelirio Castilleja de Guzmán (Sevilla). I. ESTUDIO DEL MEDIO FÍSICO Y LAS FORMACIONES SUPERFICIALES. Universidad de Sevilla (inédito), Sevilla

Bueno Ramírez P, Barroso Bermejo R, de Balbín Behrmann R (2005) Ritual campaniforme, ritual colectivo: la necrópolis de cuevas artificiales del Valle de las Higueras, Huecas, Toledo. Trab Prehist 62:67-90

Cabrero García R (1985) El sepulcro megalítico de Caño Ronco (Camas, Sevilla) y su vinculación con el yacimiento calcolítico de Valencina de la Concepción. Prehistoria 1:1-16

Cabrero García R (1988) El Yacimiento calcolítico de Los Delgados, Fuenteobejuna (Córdoba). Monte de Piedad y Caja de Ahorros de Córdoba, Córdoba

Carreira JR (1995) Escavações de Leite de Vasconcellos e Júlio César Garcia em dolmens de S. Geraldo, Montemor-o-Novo (1898-1900). Almansor 13:5-60

Cassen S, Boujout C, Dominguez Bella S et al (2012) Dépôts bretons, tumulus carnacéens et circulations à longue distance. In: Pétrequin $\mathrm{P}$, Cassen S, Errera $\mathrm{M}$ et al (eds) Jade, grandes haches alpines du
Néolithique européen: Ve et IVe millénaires av. J.-C. Presses universitaires de Franche-Comté, pp 822-871

Cerdeño ML, Martínez JA, Agua F et al (2012) Ámbar en la Meseta Oriental durante el Bronce Final: yacimientos locales e importaciones bálticas. Trab Prehist 69:375-384. https://doi.org/ $10.3989 /$ tp.2012.12098

Chapman R (1990) Emerging complexity: the later prehistory of southeast Spain, Iberia, and the west Mediterranean. Cambridge University Press

Chapman R (2003) Archaeologies of complexity. Routledge, London

Chapman R (2008) Producing inequalities: regional sequences in later prehistoric southern Spain. J World Prehist 21:195-260

Costa ME, García Sanjuán L, Murillo-Barroso M et al (2011) Artefactos elaborados en rocas raras en los contextos funerarios del IV-II milenios cal ANE en el sur de España: Una revisión. MENGA Revista de prehistoria de Andalucía 01:253-294

Daura J, Sanz M, Pike AWG et al (2010) Stratigraphic context and direct dating of the Neandertal mandible from Cova del Gegant (Sitges, Barcelona). J Hum Evol 59:109-122. https://doi.org/10.1016/j. jhevol.2010.04.009

Daura J, Sanz M, Soriano I et al (2017) Objetos de oro y epicampaniforme en la Cova del Gegant. Relaciones en la costa mediterránea de la Península Ibérica durante la Edad del Bronce. Trab Prehist 74:149. https://doi.org/10.3989/tp.2017.12188

Delclòs X, Arillo A, Peñalver E et al (2007) Fossiliferous amber deposits from the cretaceous (Albian) of Spain. Comptes Rendus Palevol 6: 135-149. https://doi.org/10.1016/j.crpv.2006.09.003

Delibes de Castro G (2011) El Pan y la Sal. La vida campesina en el Valle Medio del Duero hace cinco mil años. Real Academia de Bellas Artes de la Purísima Concepción, Valladolid

Delibes de Castro G, Rojo Guerra M, Sanz Mínguez C (1986) Dólmenes de Sedano. II. El sepulcro de corredor de Las Arnillas (Moradillo de Sedano, Burgos). Noticiario Arqueológico Hispánico (1979) 7-39

Díaz-Guardamino M, Weatley DW, Williams EF, Garrido Cordero, José Ángel (2016) CAPÍTULO 14. LOS TEXTILES ELABORADOS CON CUENTAS PERFORADAS DE MONTELIRIO. In: Fernández Flores Á, García Sanjuán L, Díaz-Zorita Bonilla M (eds) MONTELIRIO. Un gran monumento megalítico de la Edad del Cobre. JUNTA DE ANDALUCÍA. Consejería de Cultura, pp 311-344

Dominguez Bella S (2010) Objetos ornamentales en el Calcolítico del centro de la Península Ibérica. Estudio analítico de las cuentas de collar de los enterramientos prehistóricos del Valle de las higueras (toledo). In: Dominguez Bella S, Ramos Muñoz J, Pérez Rodríguez M (eds) Minerales y rocas en las sociedades de la Prehistoria. Universidad de Cádiz, Cádiz, pp 275-284

Dominguez Bella S, Bóveda MJ (2011) Variscita y ámbar en el Neolítico gallego. Análisis arqueométrico del collar del túmulo 1 de Chousa Nova, Silleda (Pontevedra, España). Trab Prehist 68:369-380. https://doi.org/10.3989/tp.2011.11075

Domínguez-Bella S, Rodríguez MAA, Muñoz JR (2001) Estudio analítico de las cuentas de collar de ámbar del dolmen de Alberite, (Villamartín, Cádiz). Naturaleza química y mineralógica e implicaciones sobre su origen. In: Pardo Rodríguez ML, Gómez Tubio B, Respaldiza Galisteo MÁ (eds) III Congreso Nacional de Arqueometría. Universidad de Sevilla, Sevilla, pp 621-630

du Gardin C (2002) L'Ambre et sa circulation dans l'europe protohistorique. In: Guilaine J (ed) Matériaux, productions, circulations du Neolithique à l'Age du Bronze. Séminaire du Collège du France, Errance, Paris, pp 213-238

Fábregas Valcarce R, Lombera Hermida A, Rodríguez Rellán C (2012) Spain and Portugal: long chisels and perforated axes. Their context and distribution. In: Pétrequin P, Errera M, Klassen L et al (eds) JADE. Grandes haches alpines du Néolithique européen, Ve et IVe millénaires av. J.-C. Presses Universitaires de Franche-Comté, Besançon, pp 1108-1135 
Fernández Flores Á, Aycart Luengo V (2013) Montelirio. Un sepulcro clave para la comprensión del registro de los grandes monumentos megalíticos de Valencina de la Concepción-Castilleja de Guzmán (Sevilla). In: García Sanjuán L, Vargas Jiménez JM, Hurtado Pérez $\mathrm{VM}$ et al (eds) El asentamiento prehistórico de Valencina de la Concepción (Sevilla): investigación y tutela en el 150 aniversario del Descubrimiento de La Pastora. Secretariado de Publicaciones, Universidad de Sevilla, Sevilla, pp 233-260

Fernández Flores Á, García Sanjuán L (2016) Capítulo 4. Arquitectura, estratigrafía y depósitos del tholos de Montelirio. In: Fernández Flores Á, García Sanjuán L, Díaz-Zorita Bonilla M (eds) MONTELIRIO. Un gran monumento megalítico de la Edad del Cobre. JUNTA DE ANDALUCÍA. Consejería de Cultura, pp 79142

Fernández Flores Á, García Sanjuán L, Díaz-Zorita Bonilla M (eds) (2016) Montelirio: Un Gran Monumento Megalítico de la Edad del Cobre. In: MONTELIRIO. Un gran monumento megalítico de la Edad del Cobre. JUNTA DE ANDALUCÍA. Consejería de Cultura

Ferreira O d V (1966) Os artefactos préhistóricos de ámbar e sua distribuição em Portugal. Revista de Guimarães 76:61-66

García-Puchol O, McClure SB, Blasco Senabre J et al (2013) Increasing contextual information by merging existing archaeological data with state of the art laser scanning in the prehistoric funerary deposit of Pastora Cave, Eastern Spain. J Archaeol Sci 40:1593-1601. https:// doi.org/10.1016/j.jas.2012.10.015

García-Puchol O, McClure SB, Cabanilles JJ et al (2012) Objetos singulares/objetos foráneos. Evidencias de circulación de artesanías en el depósito funerario del Neolítico Final/Calcolítico de la Cova de la Pastora (Alcoi, Alacant). Rubricatum: revista del Museu de Gavà 5:281-288

García Sanjuán L (2013) El asentamiento de la Edad del Cobre en Valencina de la Concepción: estado actual de la investigación, debates y perspectivas. In: García Sanjuán L, Vargas Jiménez JM, Hurtado Pérez V et al (eds) El asentamiento prehistórico de Valencina de la Concepción (Sevilla): investigación y tutela en el 150 aniversario del Descubrimiento de La Pastora. Universidad de Sevilla, Sevilla, pp 21-60

García Sanjuán L, Luciañez Triviño M, Schuhmacher TX et al (2013) Ivory craftsmanship, trade and social significance in the southern Iberian copper age: the evidence from the PP4-Montelirio sector of Valencina de la Concepción (Seville, Spain). Eur J Archaeol 0:1-26

García Sanjuán L, Murillo-Barroso M (2013) Social complexity in copper age southern Iberia (ca. 3200-2200 Cal B.C.). Reviewing the "state" hypothesis at Valencina de la Concepción (Seville, Spain). In: Cruz Berrocal M, García Sanjuán L, Gilman A (eds) The prehistory of Iberia. Debating Early Social Stratification and the State. Routedgle, New York, pp 119-140

García Sanjuán L, Scarre C, Wheatley DW (2017) The mega-site of Valencina de la Concepción (Seville, Spain): debating settlement form, monumentality and aggregation in southern Iberian copper age societies. J World Prehist. https://doi.org/10.1007/s10963-0179107-6

Gonçalves VS (1997) Olelas e Pragança : duas fortificações calcolíticas da Estremadura. Arquéologo Português S.4:8-10:31-40

Gonçalves VS (1989) Megalitismo e metalurgia no Alto Algarve Oriental. Uma aproximação integrada. UNIARQ/INIC (Estudo \& Memórias, 2), Lisbon

Gutiérrez López JM (2007) Un avance de la excavación del sepulcro megalítico de El Juncal (Ubrique, Cádiz). Revista AtlánticaMediterránea de Prehistoria y Arqueología Social 9:291-301

Havelcová M, Machovič V, Linhartová M et al (2016) Vibrational spectroscopy with chromatographic methods in molecular analyses of Moravian amber samples (Czech Republic). Microchem J 128: 153-160. https://doi.org/10.1016/j.microc.2016.04.010
Higham TF, Jacobi RM, Ramsey CB (2006) AMS radiocarbon dating of ancient bone using ultrafiltration. Radiocarbon 48:179

Horta Pereira MA (1970) Monumentos Históricos do Concelho de Mação. Mação: Câmara Municipal de Mação,

Hughes-Brock H (2011) Exotic materials and objects sent to-and from?the Bronze Age Aegean. Some recent work and some observations. In: Exotica in the prehistoric Mediterranean. pp 99-114

Hurtado V (1999) Los inicios de la complejizacion social y el campaniforme en Extremadura. SPAL 8:47-83

Hurtado V, Amores F (1982) Relaciones culturales entre el Sudeste francés y La Pijotilla (Badajoz) en el Calcolítico: las pastillas repujadas y el campaniforme cordado. Habis 13:189-209

Hurtado V, Amores F (1985) Estudio de relaciones culturales a través de fósiles directores en la Pijotilla (Badajoz). In: Extremadura U de (ed) Actas de las II Jornadas de la Metodología y didáctica de la Historía. Universidad de Extremadura, Cáceres, pp 169-193

Kosmowska-Ceranowicz B (1999) Succinite and some other fossil resins in Poland and Europe (deposits, finds, features and differences in IRS). Estudios del Museo de Ciencias Naturales de Alava 14:73117

Langenheim JH (1969) Amber: a botanical inquiry. Science 163:11571169

Lazarich González M, Fernández de la Gala J, Jenkins V, et al (2009) Paraje de Monte Bajo (Alcalá de los Gazules). Una nueva necrópolis de cuevas artificiales en el Sur de la provincia de Cádiz Almoraima: revista de estudios campogibraltareños 67-84

Leisner G, Leisner V (1943) Die Megalithgraber der Iberischen Halbinsel. Der Suden, vol 17. Textband vols. RomischeGermanische Forschungen, Berlin

Leisner G, Leisner V (1959) Die Megalithgräber der Iberischen Halbinsel: der Westen. Walther de Gruyter \& Co. 1: 2, Berlin

Leisner V (1965) Die Megalithgraser der Iberischen Halbinsel Der Western. MF, Berlin

López Quintana JC (2015) Dólmenes, cistas y menhires en la estación megalítica de Gorbeia (País Vasco): distribución geográfica y secuencia funeraria. In: Rocha L, Bueno Ramirez P, Branco G (eds) Death as archaeology of transition: thoughts and materials. BAR International Series 2708, Oxford, pp 197-218

Lorrio AJ (2008) Qurénima: el Bronce Final del sureste en la Península Ibérica. Real Academia de la Historia, Madrid

Lull V, Micó R, Rihuete Herrada C, et al (2015) La Almoloya (Pliego, Murcia). Ruta Argárica, Guías Arqueológicas n². ASOME-UAB

Machado JLS (1964) Subsídios para a história do Museu Etnológico Português Dr. José Leite de Vasconcellos. O Arqueólogo Português 5:51-448

Madeira J, Gonçalves VS, Raposo L, Parreira R (1972) Achados da Idade do Bronze no Monte da Pena (Barro, Torres Vedras) - notícia breve. O Arqueólogo Português 6:207-212

Maish J, Khanjian H, Schilling M (2012) Ancient carved ambers in the J. Paul Getty Museum: Analysis of Selected Ambers from the Collections of the J. Paul Getty Museum. http:// museumcatalogues.getty.edu/amber/techessay/. Accessed 19 Oct 2016

Marqués Merelo Iganacio, Aguado Mancha T (2012) Los enterramientos de la edad del bronce de la Provincia de Málaga

Martin Valls R, Delibes de Castro G (1989) La cultura del vaso campaniforme en las campiñas meridionales del Duero: el enterramiento de Fuente Olmedo (Valladolid). Junta de Castilla y Leon, Valladolid

Martins A (2014) O MEGALITISMO DE OURIQUE. Um Conjunto Megalítico Esquecido. MPhil Thesis, Universidad de Huelva. Departamento Historia I

McClure SB, García-Puchol O, Culleton BJ (2010) Ams dating of human bone from Cova de la Pastora: new evidence of ritual continuity in the prehistory of eastern Spain. Radiocarbon 52:25-32. https://doi. org/10.1017/S0033822200045008 
Mederos Martín A (2013) La cronología del dolmen de Montelirio (Castilleja de Guzmán, Sevilla). In: Encuentro de Arqueología del Suroeste Peninsular, Jiménez Ávila J, Bustamante M, García Cabezas M (eds) VI Encuentro de Arqueología del Suroeste Peninsular: [actas] Villafranca de los Barros, 4-6 de octubre de 2012. Ayuntamiento de Villafranca de los Barros, Villafranca de los Barros, Badajoz, pp 2597-2612

Molina Fajardo F, Cámara Serrano JA (2009) Almería. In: García Sanjuán L, Ruiz González B (eds) Las Grandes Piedras de la Prehistoria. Sitios y Paisajes Megalíticos de Andalucía. Junta de Andalucía, Sevilla, pp 32-54

Mora Molina C, García Sanjuán L, Peinado Cucarella J, Wheatley DW (2013) Las estructuras de la Edad del Cobre del Sector PP4Montelirio del sitio arqueológico de Valencina de la ConcepciónCastilleja de Guzmán (Sevilla). In: García Sanjuán L, Vargas Jiménez JM, Hurtado Pérez VM et al (eds) El asentamiento prehistórico de Valencina de la Concepción (Sevilla): investigación y tutela en el 150 aniversario del Descubrimiento de La Pastora. Universidad de Sevilla, Secretariado de Publicaciones, Sevilla, pp 261-280

Morán E, Parreira R (2004) Alcalar 7. Estudo e reabilitação de um monumento megalítico. IPPAR (Cadernos, 6), Lisbon

Morán E (2014) El asentamiento prehistórico de Alcalar (Portimão, Portugal). La organización del territorio y el proceso de formación de un estado pristino en el tercer milenio a.n.e.. PhD Thesis, Universidad of Sevilla. Departamento de Prehistoria y Arqueología

Morán E, Parreira R (2007) Alcalar. Monumentos megalíticos. IGESPAR (Roteiros da Arqueologia Portuguesa, 10), Lisbon

Mujika JA, Armendariz A (1991) Excavaciones en la estación megalítica de Murumendi (Beasain, Gipuzkoa). Munibe 43:105-165

Murillo-Barroso M (2016) CAPÍTULO 13. El ÁMBAR del tholos de MONTELIRIO. In: Fernández Flores Á, García Sanjuán L, DíazZorita Bonilla M (eds) MONTELIRIO. Un gran monumento megalítico de la Edad del Cobre. JUNTA DE ANDALUCÍA. Consejería de Cultura, pp 311-344

Murillo-Barroso M, García Sanjuán L (2013) El pomo de ámbar de la Estructura 10.042-10.049 del Sector PP4-Montelirio del asentamiento de Valencina de la Concepción (Sevilla). In: García Sanjuán L, Vargas Jiménez JM, Hurtado Pérez VM, et al. (eds) El asentamiento prehistórico de Valencina de la Concepción (Sevilla): investigación y tutela en el 150 aniversario del Descubrimiento de La Pastora. Universidad de Sevilla, Secretariado de Publicaciones, Sevilla, pp 511-520

Murillo-Barroso M, Martinón-Torres M (2012) Amber sources and trade in the prehistory of the Iberian Peninsula. Eur J Archaeol 15:187216

Negroni Catacchio N (2007) Le vesti sontuose e gli ornamenti. Monili d'ambra e di materie preziose nelle tombe femminili di età orientalizzante in Italia Scripta Praehistorica in Honorem Biba Terzan 533-556

Negroni Catacchio N (2011) Amber and the warrior princes of the Orientalissing period in Italy. In: Vianello A (ed) Exotica in the Merditerranean. Oxbow Books, Oxford, pp 74-95

Nocete F, Vargas JM, Schuhmacher TX et al (2013) The ivory workshop of Valencina de la Concepción (Seville, Spain) and the identification of ivory from Asian elephant on the Iberian peninsula in the first half of the 3rd millennium BC. J Archaeol Sci 40:1579-1592. https://doi. org/10.1016/j.jas.2012.10.028

Odriozola CP, Mataloto R, Moreno-García J et al (2012) Producción y circulación de rocas verdes y sus productos en el sw peninsular: el caso de Anta Grande do Zambujeiro. Estudos Arqueologicos de Oeiras 19:125-142

Odriozola CP, Soares J, Tavares da Silva C, Fonseca P (2016a) Iberian Southwest Middle Bronze Age Reading social complexity in greenstone beads from the cist necropolis of Sines. Setubal Arqueológica
Social complexity in a long term perspective Session B15 16:131152

Odriozola CP, Villalobos García R, Burbidge CI et al (2016b) Distribution and chronological framework for Iberian variscite mining and consumption at Pico Centeno, Encinasola, Spain. Quat Res 85:159-176. https://doi.org/10.1016/j.yqres.2015.11.010

Oliveira J (1992) A Anta dos Pombais - Beira, Marvão. Ibn Marvan 2:5189

Ontañón R (2003) Caminos hacia la complejidad. El Calcolítico en la región cantábrica. Universidad de Cantabria, Santander

Parnell AC, Buck CE, Doan TK (2011) A review of statistical chronology models for high-resolution, proxy-based Holocene palaeoenvironmental reconstruction. Quat Sci Rev 30:2948-2960. https://doi.org/10.1016/j.quascirev.2011.07.024

Pascual Benito JL (1999) Utillaje óseo, adornos e ídolos neolíticos valencianos. Diputación de Valencia, Xirivella

Pastorelli G (2009) Archaeological Baltic amber: degradation mechanisms and conservation measures. $\mathrm{PhD}$ Thesis, Alma

Peñalver E, Álvarez-Fernández E, Arias P et al (2007) Local amber in a Palaeolithic context in Cantabrian Spain: the case of la Garma a. J Archaeol Sci 34:843-849. https://doi.org/10.1016/j.jas.2006.03.006

Pereira FA (1909) Processo official do monumento préhistórico do Monte da Pena (Torres Vedras). O Arqueologo Portugués 14:354-369

Pétrequin P, Cassen S, Errera M, et al (eds) (2012) JADE. Grandes haches alpines du Néolithique européen, Ve et IVe millénaires av. J.-C. Presses Universitaires de Franche-Comté, Besançon

Poinar GO (1992) Life in amber. Stanford University Press

Renfrew C (1993) Trade beyond material. In: Scarre C, Healy F (eds) Trade and exchange in prehistoric Europe. Oxbow Books, Oxford, pp 5-16

Renfrew C (2001) Symbol before concept: material engagement and the early development of society. In: Hodder I (ed) Archaeological Theory Today. Blackwell Publishers Ltd., pp 122-140

Rice PC (2006) Amber, the golden gem of the ages. Bloomington

Riquelme Cantal JA, Ubric Rabaneda P, Delgado Blasco P, Esquivel Guerrero JA (2001) Seguimiento arqueológico y excavación de urgencia de una sepultura argárica en la Cueva de Las Ventanas, Piñar,(Granada). In: Anuario arqueológico de Andalucía 1997. Consejería de Cultura, pp 328-332

Rocha AS (1904) Dolmens de Alcalar. Boletim da Sociedade Archeologica da Figueira 2, Figueira da Foz

Rocha AS (1911) Materiaes para o estudo da Idade do Cobre em Portugal. Imprensa Lusitana de A. Veiga, Figueira da Foz

Rocha L (2005) As origens do Megalitismo funerário no Alentejo Central: a contribuição de Manuel Heleno. PhD Thesis, Universidade de Évora

Rovira i Port J (1994) Ámbar y pasta vítrea. Elementos de prestigio entre el neolítico avanzado y el bronce final del nordeste de la península ibérica. Un primer estado de la cuestión. Quad PREH ARQ CAST 16:67-91

Rovira Llorens S, Delibes de Castro G, Montero Ruiz I (eds) (2003) Las primeras etapas metalúrgicas en la península ibérica. Instituto Universitario Ortega y Gasset, Fundación José Ortega y Gasset, Madrid

Santos JF (2009) Anta Grande do Zambujeiro. Contributo para o processo de recuperação do monumento. MPhil Thesis, Universidade de Évora

Santos Arevalo FJ, Gómez Martínez I, Garcia Leon M (2009) Radiocarbon measurement programme at the Centro Nacional de Aceleradores (CNA). Radiocarbon:883-889

Santos I, Rocha L (2015) ANTA GRANDE DO ZAMBUJEIRO (ÉVORA, PORTUGAL): CONTRIBUTO P ARA O CONHECIMENTO DAS CERÂMICAS. In: Branco G, Rocha L, DUARTE C, et al. (eds) Arqueologia de Transição: O Mundo Funerário. Actas do II Congresso Internacional Sobre Arqueologia de Transição (29 de Abril a 1 de Maio 2013). CHAIA, pp 42-51 
Schubart H (1967) Las fortificaciones eneolíticas de Zambujal e Pedra do Ouro, em Portugal. In: Congreso Nacional de Arqueologia, X, Mahón, 1967 - Crónica del Congreso Nacional de Arqueologia. Secretaría General de los Congresos Arqueológicos Nacionales, Zaragoza, pp 197-204

Schuhmacher TX (2012) El marfil en España desde el Calcolítico al Bronce Antiguo. In: Barnejee A, López Padilla JA, Schuhmacher TX (eds) Elfenbeinstudien faszikel 1. Marfiles y elefantes en la península Ibérica y el Mediterráneo Occidental. Verlag Philipp von Zabern, Mainz, pp 45-68

Schuhmacher TX, Cardoso JL, Banerjee A (2009) Sourcing African ivory in Chalcolithic Portugal. Antiquity 83:983-997

Shashoua Y, Degn Berthelsen M-BL, Nielsen OF (2006) Raman and ATR-FTIR spectroscopies applied to the conservation of archaeological Baltic amber. J Raman Spectrosc 37:1221-1227. https://doi. org $110.1002 /$ jrs. 1586

Shevchenko LL (1963) Infrared spectra of salts and complexes of carboxylic acids and some of their derivatives. Russ Chem Rev 32: 201-207

de Silva M (1895) Notícia das antiguidades prehistoricas do concelho de Avis. 2: Anta da herdade da Capella. O Archeólogo Português 1: 214-216

Siret L (1893) L’Espagne préhistorique. Revue des Questiona Scientifiques XXXIV:537-560

Siret L (1913) Questions de Chronologie et d'Ethnographie Ibeŕiques. P. Geuthner, Paris

Soares J (2003) Os hipogeus pré-históricos da Quinta do Anjo (Palmela) e as economias do simbólico. Museu de Arqueologia e Etnografia do Distrito de Setúbal, Setubal

Soares J, SIlva C (2010) Anta Grande do Zambujeiro - arquitectura e poder. Intervenção arqueológica do MAEDS, 1985-87. Musa Museus, Arqueologia e outros patrimónios 3:83-129

Sousa AC (2008) Arqueologia na A21. Uma análise preliminar dos trabalhos arqueológicos 2004-2007. Boletim Cultural, Mafra 411497

Sousa AC (2016) Megalitismo e metalurgia. Os tholoi do Centro e Sul de Portugal. In: Sousa AC, CARVAlHO AF de, Viegas C (eds) Terra e Água. Escolher smentes, invocar a Deusa. Estudos de homenagem a Victor S. Gonçalves. UNIARQ (Estudos \& Memórias, 9), Lisbon, pp 209-241

Stout EC, Beck CW, Anderson KB (2000) Identification of rumanite (Romanian amber) as thermally altered succinite (Baltic amber). Phys Chem Miner 27:665-678

Sttip JJ, Tamers MA (1996). Dataciones absolutas. En El dolmen de Alberite (Villamartín). Aportaciones a las formas económicas y sociales de las comunidades neolíticas en el noroeste de Cádiz, editado por J. Ramos Muñoz y F. Giles Pacheco, 179-186. Salamanca: Servicio de publicaciones de la Universidad de Cádiz

Terradas X, Gratuze B, Bosch J et al (2014) Neolithic diffusion of obsidian in the western Mediterranean: new data from Iberia. J Archaeol Sci 41:69-78. https://doi.org/10.1016/j.jas.2013.07.023

Thomas JT (2014) Emerging economies: Late Neolithic and Copper Age beads and pendants of the Portuguese Estremadura. Graduate College of the University of Iowa

Tykot RH, Freund KP, Vianello A (2013) Source analysis of prehistoric obsidian artifacts in Sicily (Italy) using pXRF. In: Armitage RA,
Burton JH (eds) Archaeological Chemistry VIII. American Chemical Society, Washington, DC, pp 195-210

Valera AC (2012) Mind the gap: Neolithic and Chalcolithic enclosures of South Portugal. In: Gibson AM (ed) Enclosing the Neolithic: recent studies in Britain and Europe. Archaeopress, Oxford, pp 165-183

Valera AC (2013) Cronologia Absoluta dos Fossos 1 e 2 do Porto Torrão e o Problema da Datacão de Estruturas Negativas "Tipo Fosso". Apontamentos de Arqueologia e Patrimonio 9:7-11

Valera AC, Silva AM, Márquez Romero JE (2014) La temporalidad del recinto de fosos de Perdigões: cronología absoluta de estructuras y prácticas sociales. Spal Revista de Prehistoria y Arqueología de la Universidad de Sevilla:11-26. https://doi.org/10.12795/spal. 2014i 23.01

van der Werf ID, Fico D, De Benedetto GE, Sabbatini L (2016) The molecular composition of Sicilian amber. Microchem J 125:85-96. https://doi.org/10.1016/j.microc.2015.11.012

Vaquer J, Martín A, Pétrequin P, et al (2012) Les haches alpines dans les sépultures du Néolithique moyen pyrénéen: importations et influences. In: Pétrequin P, Cassen S, Errera M, et al. (eds) Jade, grandes haches alpines du Néolithique européen: Ve et IVe millénaires av. J.C. Presses universitaires de Franche-Comté, pp 872-917

Vasconcellos JL (1895) Para a história do Museu Ethnologico (de 1893 a 1908): 14 annos de luta, ralações e trabalho. O Archeologo Português S.IV. 26:245-247

Vasconcellos JL (1910) Chrónica: excursão archeológica, excavação, acquisições. O Archeólogo Português 15:247-252

Veiga S (1886) Antiguidades Monumentaes do Algarve. Tempos Prehistoricos. Imprensa Nacional. 1, Lisbon

Veiga S (1889) Antiguidades Monumentaes do Algarve. Tempos Prehistoricos. Imprensa Nacional. 3, Lisbon

Vera Rodríguez JC (2014) Dossier. La Cueva de los Cuarenta (Priego de Córdoba). Avance a los resultados de la Intervención Arqueológica de 2007. Antiquitas 71-133

Viana A (1959) Notas históricas, arqueológicas e etnográficas do Baixo Alentejo. Arquivo de Beja XVI:3-48

Viana A, Formosinho J, Ferreira O d V (1953) Algumas notas sobre o Bronze mediterrânico do Museu Regional de Lagos. Zephyrus 4: $97-117$

Vijande Vila E, Domínguez-Bella S, Cantillo Duarte JJ et al (2015) Social inequalities in the Neolithic of southern Europe: the grave goods of the Campo de Hockey necropolis (San Fernando, Cádiz, Spain). Comptes Rendus Palevol. https://doi.org/10.1016/j.crpv.2014.11. 004

Vilaça R, Beck CW, Stout EC (2002) Provenience analysis of prehistoric amber artifacts in Portugal. Madrider Mittelungen:61-78

Villalobos García R, Odriozola CP (2016) Organizing the production of variscite personal ornaments in later prehistoric Iberia: the mines of Aliste and the production sites of Quiruelas de Vidriales (Zamora, Spain). Eur J Archaeol:1-21. https://doi.org/10.1080/14619571. 2016.1147316

Whittle AWR, Arnaud JM (1975) Thermoluminescent dating of Neolithic and chalcolithic pottery from sites in Central Portugal. Archaeometry 17:5-24. https://doi.org/10.1111/j.1475-4754.1975. tb00112.x

Zbyszewski G, Ferreira O da V (1958) Estação pré-histórica da Penha Verde (Sintra). Comunicações dos Serviços Geológicos de Portugal 39:37-57 